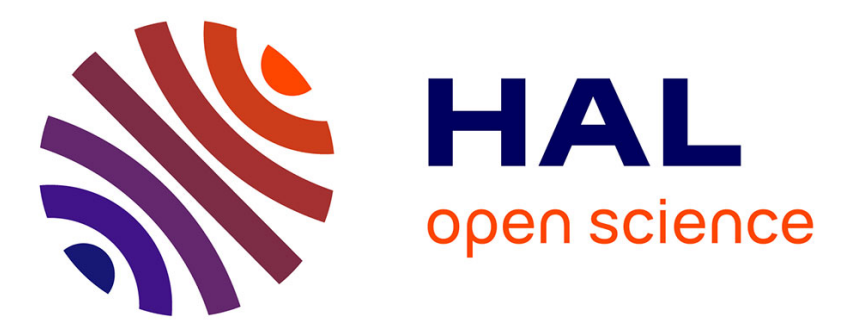

\title{
Design and synthesis of 3,5- hetero diesters of 4-deoxy quinic acid and their aphicidal activity against Acyrthosiphon pisum
}

Xiubin Li, Catherine Sivignon, Pedro da Silva, Yvan Rahbé, Yves Queneau, Sylvie Moebs-Sanchez

\section{To cite this version:}

Xiubin Li, Catherine Sivignon, Pedro da Silva, Yvan Rahbé, Yves Queneau, et al.. Design and synthesis of 3,5- hetero diesters of 4-deoxy quinic acid and their aphicidal activity against Acyrthosiphon pisum. Tetrahedron, 2021, pp.131982. 10.1016/j.tet.2021.131982 . hal-03126097

\section{HAL Id: hal-03126097 https://hal.science/hal-03126097}

Submitted on 1 Jun 2021

HAL is a multi-disciplinary open access archive for the deposit and dissemination of scientific research documents, whether they are published or not. The documents may come from teaching and research institutions in France or abroad, or from public or private research centers.
L'archive ouverte pluridisciplinaire HAL, est destinée au dépôt et à la diffusion de documents scientifiques de niveau recherche, publiés ou non, émanant des établissements d'enseignement et de recherche français ou étrangers, des laboratoires publics ou privés.

\section{()ㅜ) $\Theta$}

Distributed under a Creative Commons Attribution - NoDerivatives| 4.0 International 


\title{
Design and synthesis of 3, 5- hetero diesters of 4-deoxy quinic acid and their aphicidal activity against Acyrthosiphon pisum.
}

\author{
Xiubin Li, ${ }^{a}$ Catherine Sivignon, ${ }^{b}$ Pedro da Silva, ${ }^{b}$ Yvan Rahbé,,${ }^{b}$ Yves Queneau, ${ }^{a}$ Sylvie Moebs-Sanchez, ${ }^{a *}$ (D)
}

${ }^{a}$ Université de Lyon, INSA Lyon, ICBMS, UMR 5246 CNRS, Université Lyon 1, CPE Lyon, 1 Rue Victor Grignard, Bâtiment Lederer, F-69622 Villeurbanne Cedex, France; Tel : +33-(0)4 81929902 ; sylvie.moebs@insa-lyon.fr ORCID : 0000-0003-41971826

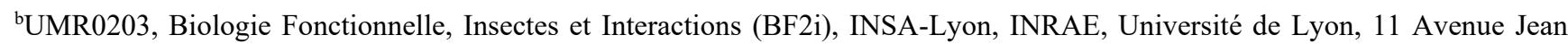
Capelle, Bâtiment Louis Pasteur, F-69621 Villeurbanne, France.

'INRAE, UMR5240, INSA-Lyon, CNRS Université Claude Bernard Lyon 1, Université de Lyon, 10 rue Dubois, Bâtiment Lwoff, F-69622 Villeurbanne cedex.

\section{Highlights}

- Analogs of chlorogenic acids featuring different and various hydroxyl cinnamoyl groups in 3 and 5 positions

- Four compounds were found to exhibit higher aphicidal activities than natural 3,5-di-O-caffeoylquinic acid

- Both acetylated 3-O-feruloyl-5-O-caffeoyl and 3-O-caffeoyl-5-O-coumaroyl compounds were active

- Observation of an interesting structure-activity difference for two regioisomers

\section{Graphical abstract}

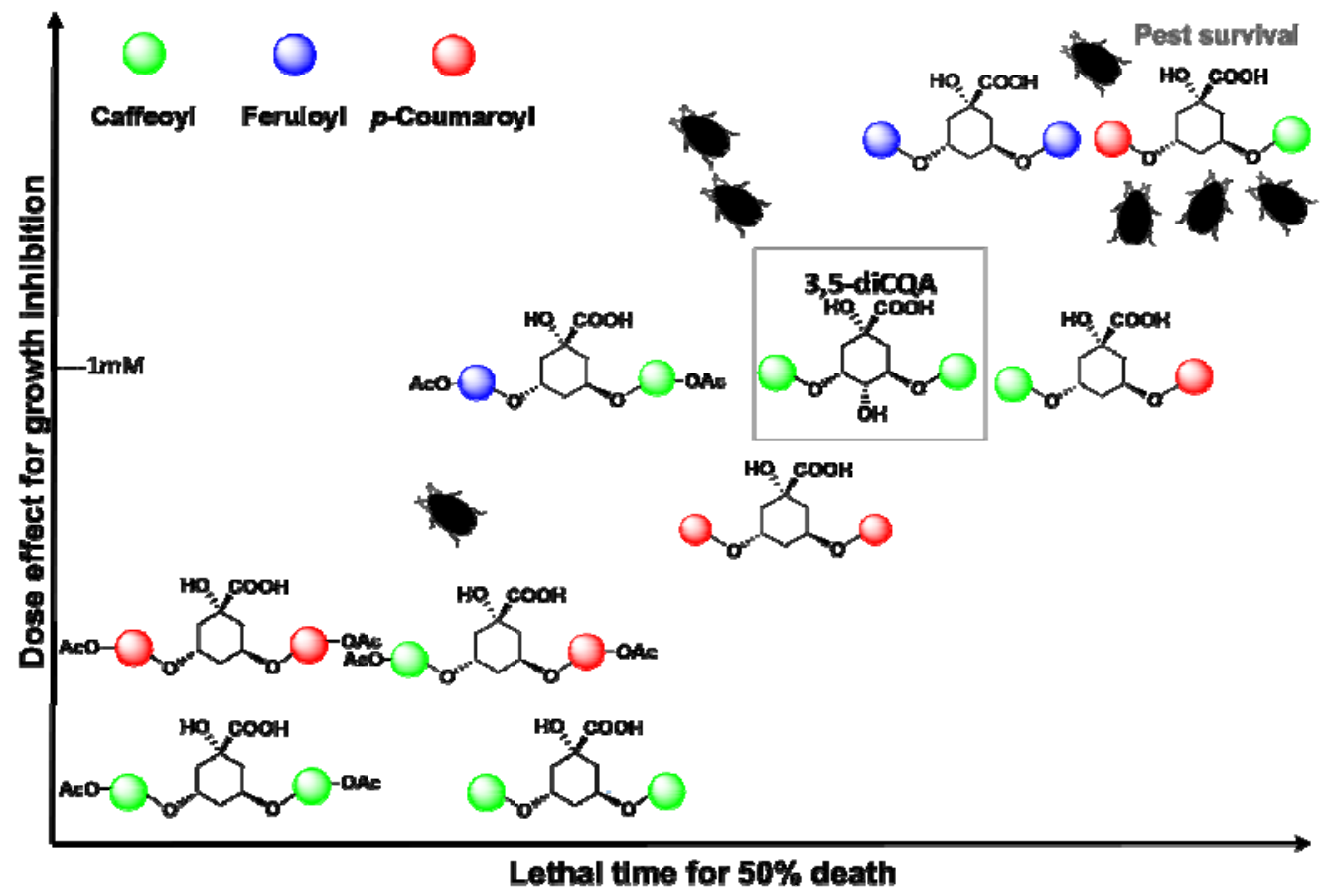

Four analogs of 3,5-dicaffeoylquinic acid, including a new heterodiester of 4-deoxyquinic acid, were found toxic against a pea aphid. Several 4-deoxy quinic analogs featuring two different hydroxyl cinnamoyl moieties in position 3 and 5 were prepared for the first time and carefully analysed. Through an assay on a pea aphid larvae, interesting indications on the structure-aphicidal activity relationships and higher levels of toxicity were observed for four compounds related to the reference natural compound.

Keywords : chlorogenic acids, deoxy quinic acid, heterodiesters, pest management, growth inhibition 


\title{
Design and synthesis of 3, 5- hetero diesters of 4-deoxy quinic acid and their aphicidal activity against Acyrthosiphon pisum.
}

\author{
Xiubin Li, ${ }^{\text {a }}$ Catherine Sivignon, ${ }^{\mathrm{b}}$ Pedro da Silva, ${ }^{\mathrm{b}}$ Yvan Rahbé,,${ }^{\mathrm{b}, \mathrm{c}}$ Yves Queneau, ${ }^{\mathrm{a}}$ Sylvie Moebs-Sanchez ${ }^{\mathrm{a}}$ (D)
}

\section{Introduction}

Aphids, like the pea aphid Acyrthosiphon pisum, are severe agricultural pests damaging crops and vectoring plant pathogens. Aphid control strategies tend to be oriented towards more sustainable measures to reply to emerging resistance issues and concerns about environmental, human health and beneficial organism preservation. Natural products are logically regarded as promising alternatives to synthetic pesticides and still source of inspiration to find potentially less noxious chemicals. ${ }^{1,2}$

Hydroxycinnamoyl quinic acids, particularly caffeoylquinic acids, are widespread edible plant secondary metabolites. Most of these compounds, mono-, di- or triesters of hydroxycinnamoyl acids and polyol quinic acid, are grouped into a family named chlorogenic acids. Commonly used via traditional herbal medicines, different in vitro bioassays have evaluated their potential biological activities, among antioxidant, ${ }^{3}$ antifungal, ${ }^{4}$ antiviral, ${ }^{5}$ renoprotective,${ }^{6}$ neuroprotective, ${ }^{7,8}$ inhibitors of $\alpha$-glucosidase,${ }^{9,10}$ or as modulators of the intestinal microbiota in high-fat-diet-fed mice. ${ }^{11}$

The underlying biological mechanisms for host plant resistance to aphids are worth of interest. ${ }^{12}$ For example, the correlation between chlorogenic acids concentration and priming of plants ${ }^{13}$ was shown for the carrot fly larval damage, ${ }^{14}$ for fungal infection ${ }^{4}$ or for cultured tobacco cells. ${ }^{15}$ The resistance of lettuce cultivars to Pemphigus bursarius ${ }^{16}$ or the negative effect of chlorogenic acid on Western flower thrips Frankliniella occidentalis were also reported. ${ }^{17}$ The cultivar Rubira peach tree, parent of a trait mapped to Rm2 gene $^{18}$ had shown a strong induced resistance to Myzus persicae, the green peach aphid which represents a threat for many agroindustrial crops. ${ }^{19}$ An accumulation of metabolite, later identified as 3,5-dicaffeoyl quinic acid 1 (3,5-diCQA), had been previously detected in aphid-infested leaves, ${ }^{20}$ and also later observed in a fungal-pear tree pathosystem. ${ }^{21}$ While aphicidal activity was demonstrated by positive preliminary results of in vitro artificial diets assays adding 1 in nutritive medium for aphids, ${ }^{22}$ the biological mode of action is not yet elucidated. To get preliminary insight into the structure activity relationship and/or to find more active compounds, we had considered the preparation of various synthetic analogs. To prevent isomerization of dihydroxycinnamoyl quinic acids during in vitro assays, ${ }^{22,23}$ model compounds with a 4-deoxy quinic acid nucleus had been designed. Eight hydroxycinnamoyl homodiesters of a new 4-deoxy quinic acid or its methyl ester had been synthesized from the new triol 4. ${ }^{24}$ Their influence on the feeding behaviour of the pea aphid Acyrthosiphon pisum was evaluated. Two homodiesters with a free carboxylic function, compounds $\mathbf{2 a}$ and $\mathbf{2 b}$, namely "3,5-dicaffeate" and "3,5-dicoumarate" had been identified as more toxic than the natural 3,5-diCQA 1 (Figure 1).<smiles>O=C(/C=C/c1ccc(O)c(O)c1)O[C@@H]1[C@@H](OC(=O)/C=C/c2ccc(O)c(O)c2)[C@H](O)C(O)(C(=O)O)[C@H]1O</smiles><smiles>[R9][C@H]1C[C@@H]([R9])C[C@@](O)(C(=O)O)C1</smiles><smiles>[R][R]</smiles>

$$
4 \mathrm{R}=\mathrm{H} \quad \mathrm{R}^{\prime}=\mathrm{H}
$$

From previous work Homodiesters $\mathbf{R}=\mathbf{R}^{\prime}$

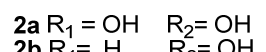
$\begin{array}{ll}2 a R_{1}=O H & R_{2}=O H \\ 2 b R_{1}=H & R_{2}=O H \\ 3 a R_{1}=O M e & R_{2}=O A c \\ 3 b R_{1}=H & R_{2}=O A c\end{array}$ $\begin{array}{ll}3 \mathrm{~b} \mathrm{R}_{1}=\mathrm{H} & \mathrm{R}_{2}=O A c \\ 3 c \mathrm{R}_{1}=\mathrm{OAc} & \mathrm{R}_{2}=\mathrm{OAc}\end{array}$

This work Heterodiesters $\mathbf{R} \neq \mathbf{R}^{\prime}$

Compounds 15-20

Figure 1 : Representative compounds discussed in this paper

To extend our study with a second growth inhibition assay, different other structural parameters were adressed. As a very low activity was measured for methyl esters derivatives, only carboxylic acids would be included. First, some previously described but not assayed intermediates, $\mathbf{3 a}, \mathbf{3 b}, \mathbf{3} \mathbf{c}$ could be incorporated in this new investigation to determine the influence of the acetylation of the phenol(s). Secondly, we aimed to study the possible correlation between aphicidal activity and consistent structural modifications 
such as heterosubstitution in C-3 and C-5 positions and so the putative influence of the stereochemical position of each hydroxycinnamoyl group. To refine our previous results, some questions were addressed: are two caffeoyl or $p$-coumaroyl groups mandatory for such activity and if not, is their position in C-3 or C-5 determinant? We thus designed other diesters among which those featuring a single caffeoyl and/or a single $p$-coumaroyl residues. We could anticipate that such preparation would require a clear structural elucidation of defined intermediates to identify regioisomers. Natural caffeoyl-feruloyl quinic acids are interesting «hybrids» not well studied albeit their probable existence was first noted in $1965 .{ }^{25}$ Characterization for such compounds were then however proposed by $\mathrm{NMR}^{26,27,28,29,30}$ or by LC-MS ${ }^{\mathrm{n}}$ analysis of a methanolic coffee bean extract ${ }^{31}$ or of sweet potato Ipomea batatas from China. ${ }^{32}$ Synthesis of methyl muco-quinates, heterosubstituted in 1 and 3 positions, was reported by Jaiswal et al. ${ }^{33}$ To the best of our knowledge, there were no reported synthesis for other 3,5-hetero diacylquinic acids. Here we describe our results on the preparation of novel heterocinnamoyl chlorogenic acid analogs : "hybrid diesters or heterodiesters" of 4-deoxy quinic acid 4 (Figure 1) were synthesized, carefully characterized and a complementary evaluation of the toxicity of eight compounds against the pea aphid Acyrthosiphon pisum is reported.

\section{Results and discussion}

Partial selectivity observed during monoesterifications of other quinate derivatives ( $\mathrm{Li}, \mathrm{X}$. unpublished results) encouraged us to embark into the preparation of newly designed heterodiesters by a sequential procedure, starting from the methyl 4-deoxy quinate 4, of two consecutive esterifications with different cinnamoyl chlorides. The first and key step was to identify reproducible conditions of preparation, isolation and characterization of defined monosubstituted compounds from $4^{24}$ bearing a caffeoyl, feruloyl or $p$ coumaroyl residue on the 3 or 5 positions (Scheme1). Then a second different cinnamoyl chloride could be introduced towards different combinations of 3,5-heterodiesters of $\mathbf{4}$ and then selective deprotections would give 3, 5-heterodiesters of 4-deoxy quinic acid with acetylated or free phenols.

\section{Synthesis of monoesters}
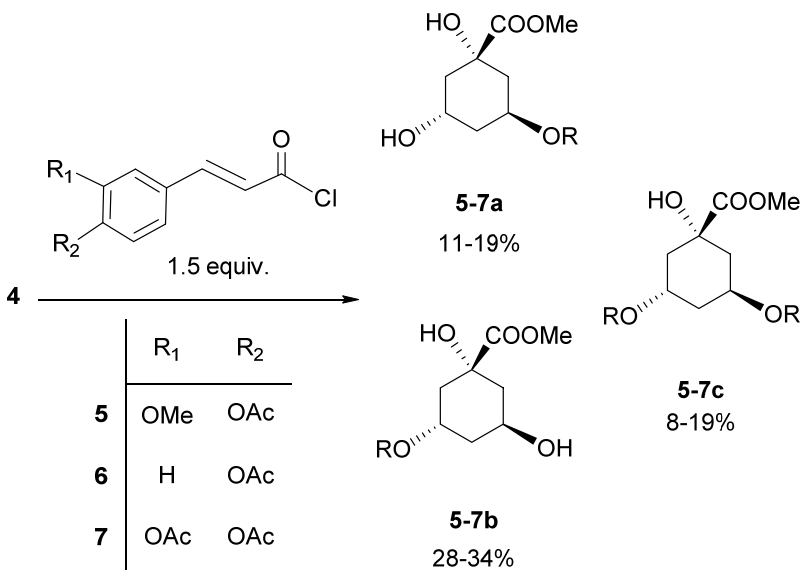

Scheme 1 : Synthesis of monoesters. Reagents and conditions. For 5 and 6 : Conditions A DMF/Pyridine $3 / 2,0.4 \mathrm{M}$ at $45^{\circ} \mathrm{C}, 4 \mathrm{~h}-$ 6h : 5a (15\%): 5b (33\%) 5c (18\%); 6a (19\%); 6b (28\%); 6c (19\%); For 7 Conditions B $\mathrm{CH}_{2} \mathrm{Cl}_{2} / \mathrm{Pyridine}^{2} / 1$, DMAP 20 mol. \%, $0.1 \mathrm{M},-18^{\circ} \mathrm{C}-0^{\circ} \mathrm{C}$ to r.t, $4 \mathrm{~h}: 7 \mathbf{a}(11 \%) ; 7 \mathbf{b}(34 \%) ; 7 \mathbf{c}(8 \%)$.

To get an optimal conversion of $\mathbf{4}$ in reaction with acetylated feruloyl, $p$-coumaroyl or caffeoyl chloride into monoesters 5-7a/b and to limit the formation of homodiesters 5-7c resulted in reacting 4 with 1.5 equiv. acyl chloride under previously identified conditions. ${ }^{24} \mathrm{~A}$ conversion rate of about $65 \%$ and a ratio monoesters/3,5-diester up to $2.7 / 1$ could be reached. Best results were obtained under these conditions with feruloyl chloride and p-coumaroyl chloride (Scheme1). With caffeoyl chloride, a disappointing even distribution forced to switch to more usual conditions, in $\mathrm{CH}_{2} \mathrm{Cl}_{2} /$ Pyridine/DMAP, with an addition of caffeoyl chloride at $0^{\circ} \mathrm{C}$ favouring $\mathbf{7 b}$, isolated with $34 \%$ yield on a $600 \mathrm{mg}$ scale of $\mathbf{4}$ (details in Table $\mathrm{S} 1$ ).

\section{NMR identification of the 3 and 5-substituted isomers}

Despite moderate yields and selectivity, isolated monoesters 5-7a and 5-7b could be all isolated for characterization after the successful, albeit tedious, chromatographic separation of main products, diester, monoesters and unreacted triol $4:$ the structural identification of each members of the pairs of 3-O or 5-O monoesters 5-7 a or $\mathbf{b}$ was indeed required for the formation of defined heterodiesters. 
The position of the esterification in monoesters $\mathbf{5 a} / \mathbf{5 b}, \mathbf{6 a} / \mathbf{6} \mathbf{b}$ or $\mathbf{7 a} / \mathbf{7} \mathbf{b}$ was determined using complete 1D-2D NMR analysis. Despite ${ }^{1} \mathrm{H}$ NMR spectra in $\mathrm{CDCl}_{3}$ for $\mathbf{5 a} / \mathbf{5 b}$ are very close (Figure2, left) (similar analysis could be done for $\mathbf{6 a} / \mathbf{6} \mathbf{b}$ and $\mathbf{7 a} / \mathbf{7} \mathbf{b}$, see supporting information), a slight discrimination could be however done in the 3.0-6.0 ppm region where could be found the respective signals for : $\mathrm{H}-3, \mathrm{H}-5, \mathrm{OH}-1, \mathrm{COOCH}_{3}$ and the unaffected $\mathrm{OH}$ in position 3 or 5 (Figure 2, right). Esterification of the OH-1, the tertiary hydroxyl group, was first discarded as in both spectra, the signal of one proton (H-3 or H-5) shifted downfield from 4.2-4.4 ppm for $\mathbf{4}$ to 5.3-5.6 ppm for 5a or $\mathbf{5 b}$.
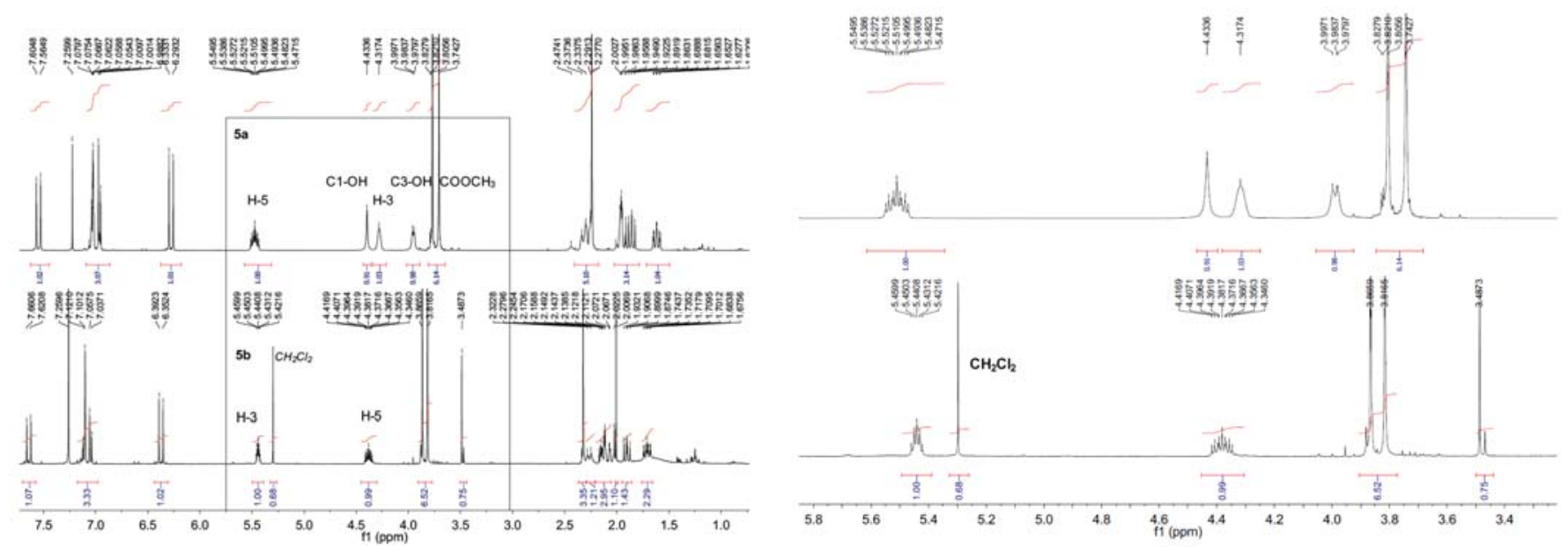

Figure 2 Left : ${ }^{1} \mathrm{H}$ NMR spectra in $\mathrm{CDCl}_{3}$ for isolated monoesters $\mathbf{5 a} / \mathbf{5 b}$; Right :Zoom on the 3.0-6.0 ppm region

The large trans-diaxial coupling constant measured between the axial proton $\mathrm{H}-4 \mathrm{a}$ (1.5-2.5 ppm) and one of the proton $\mathrm{H}-3$ or $\mathrm{H}-$ 5 (about ${ }^{3} \mathrm{~J}$ 10.3-11.5 Hz for monoesters $\mathbf{5 a} / \mathbf{5 b}$ ) supports more favoured chair conformations of 3-and 5-cinnamoyl monoesters as depicted in Scheme 2 (H-4a and trans-diaxial configuration in bold). Moreover, the carboxyl or the carboxymethyl groups were found preferentially in an equatorial conformation in quinic derivatives. ${ }^{34}$
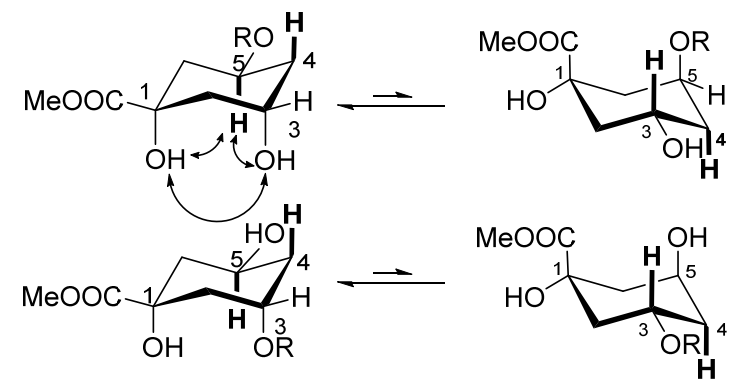

5-7a<smiles>[R]O[C@H]1C[C@@H](O)[C@H](O)C[C@]1(O)C(C)=O</smiles>

5-7b<smiles>[R6]OC(=O)[C@@]1(O)C[C@@H]([R9])C[C@@H](O)C1</smiles>

\section{Scheme 2 : Chair conformations of 5- and 3-cinnamoyl monoesters of methyl deoxy quinate 5-7a and 5-7b}

First, according to the ${ }^{1} \mathrm{H}-{ }^{13} \mathrm{C}$ HSQC 2D NMR spectrum of monoester 5a (Figure 3, left), the signals at $5.51 \mathrm{ppm}\left({ }^{3} \mathrm{~J} 11.2 \mathrm{~Hz}\right.$ and ${ }^{3} \mathrm{~J} 4.4 \mathrm{~Hz}$ ) and at $4.35-4.28 \mathrm{ppm}$ were assigned to a secondary carbon $\mathrm{CH}$ proton at the esterified position (thus $\mathrm{H}-3$ or $\left.\mathrm{H}-5\right)$ and to the other (H-5 or H-3) proton respectively. Then, thanks to ${ }^{1} \mathrm{H}-{ }^{13} \mathrm{C}$ HMBC correlations (Figure 3, right), the signal at 4.43 ppm could be assigned to the tertiary hydroxyl group $\mathrm{C} 1-\mathrm{O} \underline{\mathbf{H}}$ and the one at $4.00 \mathrm{ppm}$ to $\mathrm{C} 3$ or $\mathrm{C} 5-\mathrm{O} \underline{\mathbf{H}}$. 

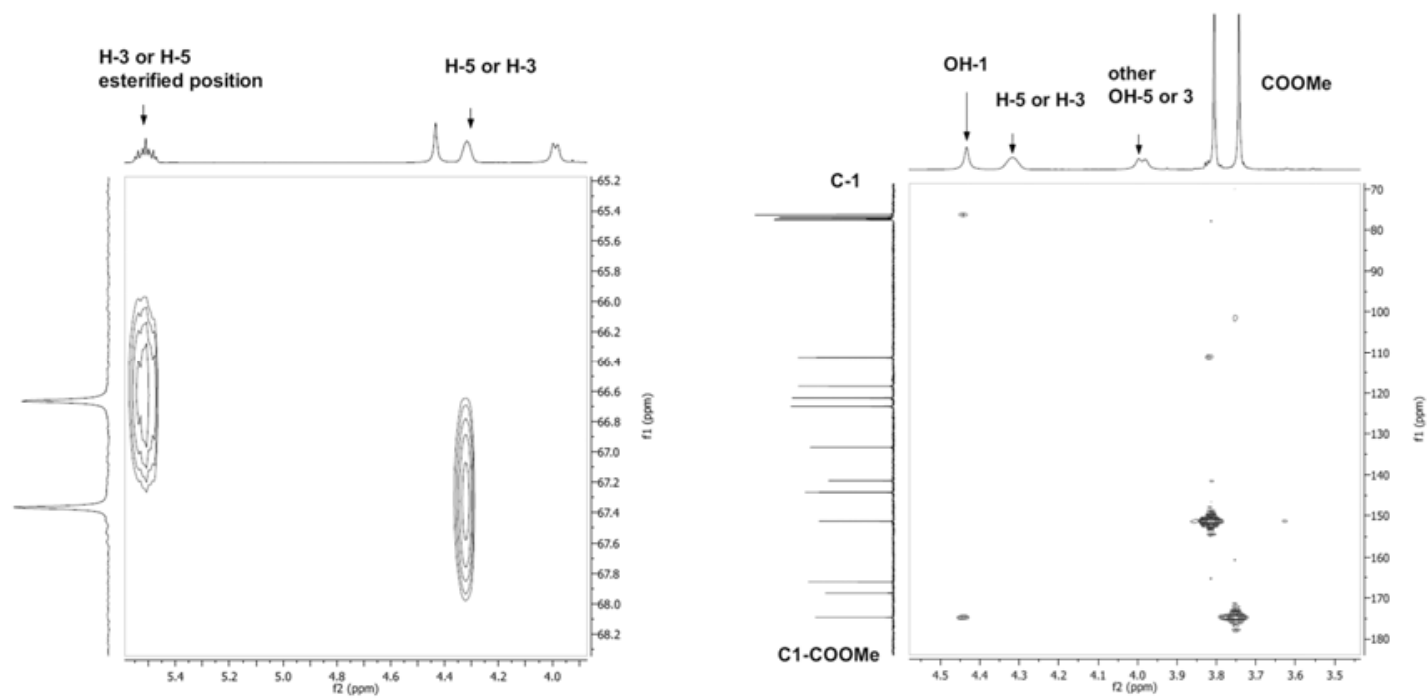

Figure 3 : 2D NMR analysis of 5a $\left(\mathrm{CDCl}_{3}\right)$ : Left: Partial ${ }^{1} \mathrm{H}_{-}{ }^{13} \mathrm{C} \mathrm{HSQC}\left(\mathrm{CDCl}_{3}\right)$; Right: Partial ${ }^{1} \mathrm{H}_{-}{ }^{13} \mathrm{C} \mathrm{HMBC}\left(\mathrm{CDCl}_{3}\right)$

In ${ }^{1} \mathrm{H}-{ }^{1} \mathrm{H}$ NOESY spectrum (Figure 4), the two such assigned signals for hydroxyl groups $\mathrm{C} 1-\mathrm{OH}$ and $\mathrm{C} 3$ or $\mathrm{C} 5-\mathrm{OH}$ exhibit interactions with each other (rectangles in Figure 4) indicating their relative cis positions, which is only consistent with a mean conformation for 5-feruloyl monoester 5a (Scheme 2). Additionally, the signal for an axial proton at 5.51 ppm is also correlated (circles in Figure 4) with these two signals for hydroxyl groups. 5a corresponds to a monoester with a feruloyl group in position 5 with a predominant conformation with an equatorial methyl ester group in $\mathrm{CDCl}_{3}$ and $\mathbf{5 b}$ is the 3-O-isomer (Scheme 1). The acylation positions of $p$-coumaroyl and caffeoyl in other monoesters $6 \mathbf{a} / \mathbf{6} \mathbf{b}$ and $7 \mathbf{a} / 7 \mathbf{b}$ were analogously confirmed.

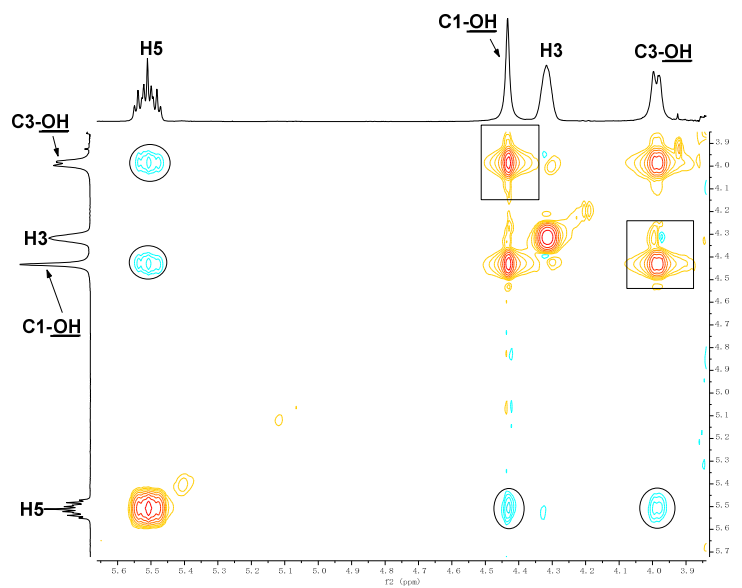

Figure 4: ${ }^{1} \mathrm{H}-{ }^{1} \mathrm{H}$ NOESY (in $\mathrm{CDCl}_{3}$ ) of $\mathbf{5 a}$

\section{Preparation of various heterodiesters}

Compounds with various combinations of the three chosen hydroxycinnamoyl moieties were targeted: replacing one of active coumaroyl residue (from 2b) by a feruloyl or caffeoyl one (Scheme 3, 9-12), or a caffeoyl (from 2a) by a feruloyl or coumaroyl residue (11-14). 9, 10, 11 could be prepared from 5a, 6a or 7a with 43\%, 75\% or 62\% isolated yields using the appropriate acyl chloride $8 \mathbf{a}$ or $8 \mathbf{b}$ (Scheme 3). The reaction between $7 \mathbf{b}$ and $8 \mathbf{b}$ at $0^{\circ} \mathrm{C}$ led to $\mathbf{1 2}$ in $69 \%$ yield while the reverse combination using $6 \mathbf{a}$ and 8c was unproductive to get 12. Interestingly coupling 7a with 8c provided 13 in reproducible yields $54-62 \%$ whatever the conditions. Surprisingly, despite our efforts to find the right combination as for $\mathbf{1 2}$, in coupling either $\mathbf{5 a}$ and $\mathbf{8 c}$ or $\mathbf{7 b}$ and $\mathbf{8 a}$, we never managed to get a pure sample of the isomer $\mathbf{1 4}$ from a partial conversion outcome and a too complex crude mixture. 


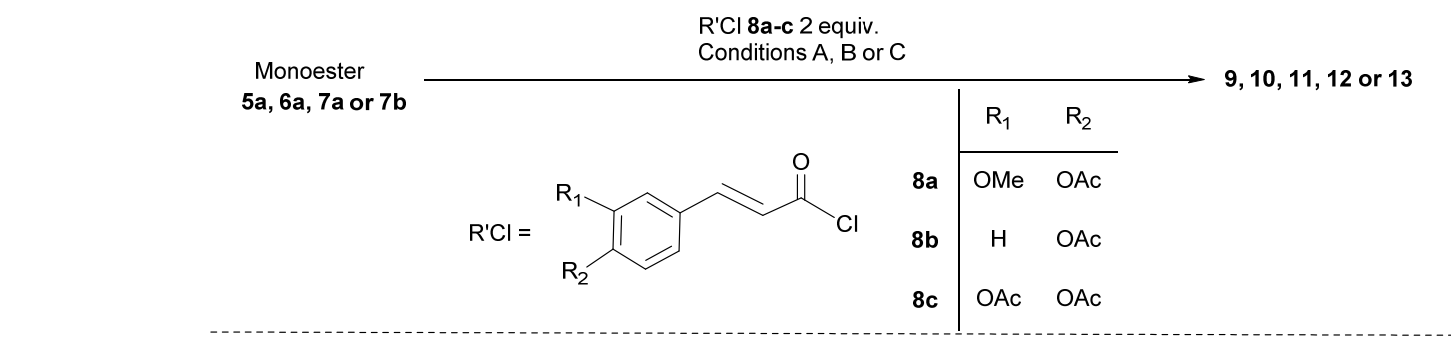<smiles>COc1ccc(/C=C/C(=O)O[C@H]2CC(OC(=O)/C=C/c3ccc(OC(C)=O)c(OC)c3)C[C@](O)(C(C)=O)C2)cc1</smiles><smiles>CC(=O)Oc1ccc(/C=C/C(=O)O[C@H]2CC(OC(=O)/C=C/c3ccc(OC(C)=O)c(OC(C)=O)c3)C[C@](O)(C(C)=O)C2)cc1</smiles>
A: $62 \%$<smiles>COc1ccc(/C=C/C(=O)O[C@H]2CC(OC(=O)/C=C/c3ccc(OC(C)=O)c(OC(C)=O)c3)C[C@](O)(C(C)=O)C2)cc1OC</smiles>

13 B : $62 \%$

C : $54 \%$<smiles>COc1ccc(/C=C/C(=O)O[C@H]2CC(OC(=O)/C=C/c3ccc(OC(C)=O)cc3)C[C@](O)(C(C)=O)C2)cc1OC</smiles>

10

A : $75 \%$<smiles>CC(=O)Oc1ccc(/C=C/C(=O)OC2C[C@@H](OC(=O)/C=C/c3ccc(OC(C)=O)c(OC(C)=O)c3)C[C@](O)(C(C)=O)C2)cc1</smiles>

12<smiles>COc1ccc(/C=C/C(=O)OC2C[C@@H](OC(=O)/C=C/c3ccc(OC(C)=O)c(OC(C)=O)c3)C[C@](O)(C(C)=O)C2)cc1OC</smiles>

Scheme 3 : Synthesis of heterodiesters. Reagents and conditions ${ }^{\text {a }}$ For 9-11 Conditions A : DMF/Pyridine $3 / 2$ at $45^{\circ} \mathrm{C}$; For 12 Conditions B : DMF/Pyridine $3 / 2$ at $0^{\circ} \mathrm{C}$ to rt; For $1362 \%$ in conditions A; $62 \%$ in conditions B; $54 \%$ in conditions C: DCM/Pyridine $5 / 1$, DMAP $20 \%$ at $0.1 \mathrm{M}$, from $0^{\circ} \mathrm{C}$ to room temperature.

\section{Cleavage of protecting groups}

Targeted compounds had to exhibit a carboxylic acid group on C-1 but either with acetylated or free phenols groups on the hydroxycinnamoyl moiety. Due to required optimisation and tedious purifications for each multi-step synthesis, 9 and 10 featuring feruloyl groups, unfortunately had to be discarded for the next steps, insufficient amounts of pure samples being obtained. Indeed to run insecticidal assays within a given time and with a representative amount of selected samples, responding to the questions addressed above, only 11, 12 and $\mathbf{1 3}$ were engaged into the next steps. A first transformation of the methyl esters led to the three corresponding carboxylic acids 15, 16, 17 subsequently giving 18, 19, 20 in quantitative yields after the cleavage of aromatic acetates (Scheme 4).
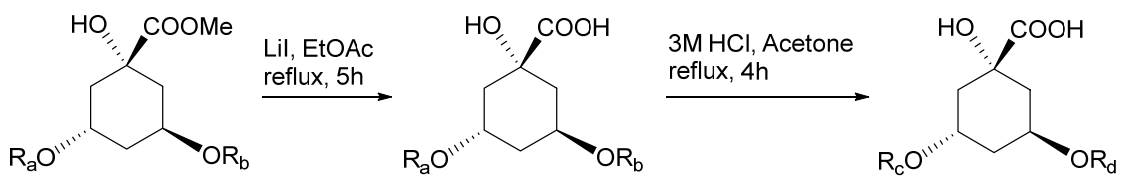

$11,12,13$

$15,16,17$<smiles>[R]c1ccc(C=CC(C)=O)cc1[R]</smiles>

$18,19,20$

$$
R_{a}, R_{b}, R_{c}, R_{d}=
$$

Scheme 4 : Cleavage of protecting groups 
The structural similarity makes difficult the discrimination of positional and geometric isomers of acyl quinic acids. To fulfil some limits of IR or NMR spectral methods, Kuhnert, Clifford and collaborators have developed a structure-diagnostic LC-MS ${ }^{\mathrm{n}}$ for monoacyl and diacyl chlorogenic acids ${ }^{31}$ or methyl esters ${ }^{35}$ without the need to isolate the pure compounds. This identification method is based on the selective $\mathrm{MS}^{\mathrm{n}}$ fragmentation pattern observed in tandem mass spectra of chlorogenic acids. Previous characterization of caffeoyl-feruloyl quinic acids ${ }^{31}$ and of 3,5-caffeoyl-p-coumaroyl quinic acids ${ }^{36}$ showed that discrimination was possible between regioisomers according to $\mathrm{MS}^{\mathrm{n}}$ spectra ( $\mathrm{n}=2$ to 3 ): $\mathrm{m} / \mathrm{z}$ values for base peaks but also peak intensities for secondary ions already differ in $\mathrm{MS}^{2}$ from the two regioisomers of heterodiesters. Indeed targeted $\mathrm{m} / \mathrm{z} 499$ for parent ion of 3, 5-caffeoyl- $p$ coumaroyl quinic acids gave either fragment-targeted $\mathrm{MS}^{2} \mathrm{~m} / \mathrm{z} 337$ (first loss of caffeoyl in position 5) or $\mathrm{m} / \mathrm{z} 353$ (first loss of $p$ coumaroyl in position 5). ${ }^{36}$

We were keen to compare such analysis on regioisomers deoxy compounds $\mathbf{1 8}$ and 19. The two compounds were indeed separable by chromatography and a same $\mathrm{m} / \mathrm{z} 483$ for the parent $[\mathrm{M}-\mathrm{H}]$ ion was found. $\mathrm{MS}^{2}$ spectra revealed a difference as base peaks found either at $\mathrm{m} / \mathrm{z} 321$ for $\mathbf{1 8}$ which corresponds to the loss of a caffeoyl residue instead of m/z 337 resulting of a loss of $p$-coumaroyl moiety for 19. Secondary peaks at $\mathrm{m} / \mathrm{z} 163$ and 179 respectively are characteristic of $p$-coumaroyl and caffeoyl fragments. ${ }^{31}$ The identifications of $\mathbf{1 8}$ as the 3-p-coumaroyl-5-caffeoyl-4-deoxy quinic acid and $\mathbf{1 9}$ as the 3-caffeoyl-5-p-coumaroyl -4-deoxy quinic acid are also consistent with an acylating residue first removed in position 5 in the deoxy series (see Supporting Information).

\section{Mortality data and growth inhibition assay over nymphal development ( 7 days) of the pea aphid Acyrthosiphon pisum}

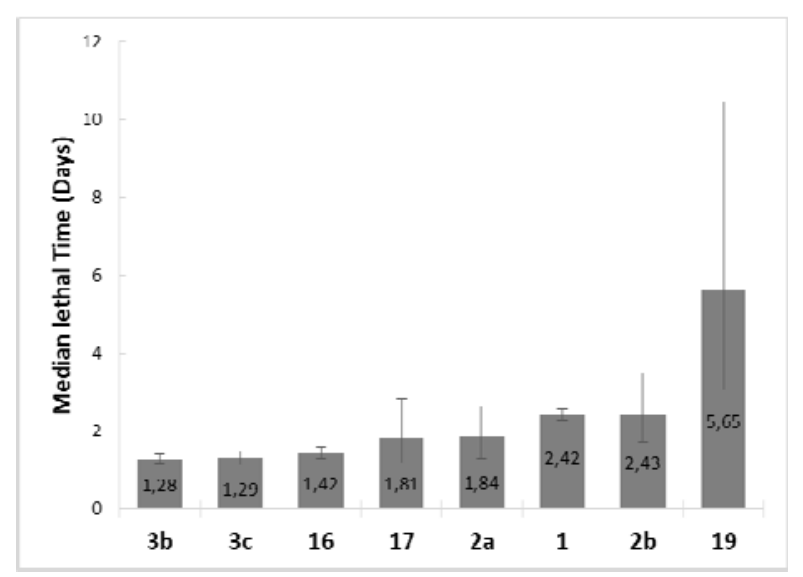

Figure 5 : Survival analysis. Lethal Time $\mathrm{LT}_{50}$ mean values per active compound $(0.5 \mathrm{mM})$

3a, 18, 20 giving a mean $\mathrm{LT}_{50}$ superior to 20 days are not represented

Together with the three acetylated homodiesters $\mathbf{3 a - 3} \mathbf{c},{ }^{24}$ five heterodiesters $16,17, \mathbf{1 8}, \mathbf{1 9}, 20$ were included in a new assay in comparison with the natural compound $\mathbf{1}$. The total available amount of acetylated heterodiester $\mathbf{1 5}$, isomer of $\mathbf{1 6}$, had to be dedicated to the preparation of $\mathbf{1 8}$, isomer of $\mathbf{1 9}$. Influence of the regioisomeric position of the more active caffeoyl and coumaroyl residues was yet possible.

Bioassays were first scored for mortality data, summarized as median lethal time $50 \%\left(\mathrm{LT}_{50}\right)$ resulting from a survival analysis (i.e. the median time necessary for killing $50 \%$ of the insect population). All concentrations were analysed separately in a parametric survival analysis with a log-normal fit, taking the "compound" as a factor (nominal, 9 levels). Dose $0.5 \mathrm{mM}$ gave the most discriminating analysis (likelihood ratio test with a $\chi 2$ of $262.1, \mathrm{p}=4.9 \mathrm{e}^{-39}$ ), and we will only discuss this dose level. One may summarize the activity (toxicity) of the eight tested compounds as follows, by decreasing activities (mean $\mathrm{LT}_{50}$, in days, and confidence interval under log-normal model, see supporting information). Results are summarized in Figure 5 (3a, 18, 20 giving a mean $\mathrm{LT}_{50}$ superior to 20 days are not represented). Three compounds, $\mathbf{3 b}, \mathbf{3 c}$ and $\mathbf{1 6}$ appeared more toxic than $\mathbf{1}$ at $0.5 \mathrm{mM}$ while results obtained for $\mathbf{1 7}$, like previously tested $\mathbf{2 a}$, includes median lethal time $50 \%\left(\mathrm{LT}_{50}\right)$ for $\mathbf{1}$. This confirms the correlation between the structural requirements of at least one caffeoyl or $p$-coumaroyl residue to compete with $\mathbf{1}$ as diferulate $\mathbf{3 a}$ also led to weak mortality. Moreover, in general, the activity range of acetylated compounds displayed more apparent toxicity than phenolic compounds. ${ }^{24}$ For example at a $0.5 \mathrm{mM}$ dose level, 1.29 days [1.12-1.48] was measured for acetylated 3c in comparison with 1.84 days [1.29-2.62] for the deacetylated derivative 2a, whereas 1.28 days[1.15-1.42] was found for acetylated $\mathbf{3 b}$ vs 2.43 days [1,713.48] for the deacetylated derivative $\mathbf{2 b .} 16$ and $\mathbf{1 7}$ are also more active than $\mathbf{1 9}$ and $\mathbf{2 0}$ respectively. If only one deacetylated caffeoyl residue is present in C-5 position, combined with a p-coumaroyl (18) or a feruloyl residue (20), median $\mathrm{LT}_{50}$ at $0.5 \mathrm{mM}$ overpasses 20 
days. Notably, this drops down to 5.65 days for $\mathbf{1 9}$, regioisomer of $\mathbf{1 8}$. When acetylation is maintained, the structural requirement of a dihydroxycinammoyl over a hydroxycinnamoyl residue seems minimized (same mortality range for $\mathbf{3 b}, \mathbf{3 c}$ and $\mathbf{1 6}$ ).

Growth over nymphal development was analysed afterwards by a set of two one-way ANOVA (Table 1), comparing either the dose effects per compound (capital lettering) or the compound effect, dose per dose (small lettering). As four independent experiments (Experiments 1-4) were needed to score all compounds, a standard normalisation of data by the results of the control condition (diet alone) was performed. Using this normalisation for weights resulted in a quite reproducible scoring of growth inhibition for the control natural molecule 1 used for every experimental batch: a two way ANOVA for dose/experiment, with interactions, resulted in a very significant "dose" effect $(p<0.001)$, and a non-significant interaction $(p=0.23)$. The effect of 1 was therefore represented in Table 1 by the global results of the 4 batches used for this molecule. These growth inhibition analyses confirmed that $3 \mathbf{c}$ is the most active compound as at $125 \mu \mathrm{M}$, total inhibition had occurred over 7 days. A concentration of $250 \mu \mathrm{M}$ was required to reach the same activity for $\mathbf{3 b}$ and $\mathbf{1 6}$ and $1 \mathrm{mM}$ for $\mathbf{1}$. Albeit acetylated, "diferulate" 3a showed no inhibitory effect below $1 \mathrm{mM}$. Results obtained for deacetylated heterodiesters $\mathbf{1 8}$ and $\mathbf{1 9}$, in comparison to respective homodiesters dicaffeate $\mathbf{2 a}$ and dicoumarate $\mathbf{2 b}$ (found more active than $\mathbf{1}$ in our first study at $125 \mu \mathrm{M}$ and $500 \mu \mathrm{M}$ respectively) showed the benefit of homosubstitution on toxicity to surpass the activity of $\mathbf{1}$. If only one dihydroxycinnamoyl residue is present in C-5 position, growth inhibition was limited (positive control at day 7 at $1 \mathrm{mM}$ for $\mathbf{1 8}$ and 20). No survivor at day 7 was however observed for $1 \mathrm{mM}$ of $\mathbf{1 9}$, regioisomer of 18. The same dose for total inhibition was required for compound $\mathbf{1 7}$ featuring an acetylated feruloyl residue. The most striking phenotypical effect, observed with $\mathbf{3 b}, \mathbf{1 6}, \mathbf{1 7}, \mathbf{1 8}, \mathbf{1 9}, \mathbf{2 0}$ compound intoxication, was a statistically significant growth impairment of the surviving pea aphids at all doses in comparison of those in the control experiment, with an increased growth inhibition with increased doses (Table 1). As a result from all the "compound" factor ANOVAs (dose by dose), that read vertically in Table 1, one might rank the global toxicity index of compounds as: $\mathbf{3 c}>\mathbf{3 b} \approx \mathbf{1 6}>\mathbf{1 9}>\mathbf{1 7} \approx \mathbf{1}>\mathbf{1 8} \approx \mathbf{2 0}>\mathbf{3 a}$.

Table 1: Growth inhibition assay over nymphal development (7 days) of the pea aphid Acyrthosiphon pisum. Results are shown as means (\% of control growth) $\pm \mathrm{SE}$, with ANOVA and mean comparisons (Tukey-Kramer HSD test) over lines (dose effect, capital lettering, $\rightarrow$ ) and over columns (molecule effect, small lettering, $\boldsymbol{\Downarrow}$ ).

\begin{tabular}{|c|c|c|c|c|c|c|c|c|}
\hline \multicolumn{3}{|c|}{ control } & \multicolumn{2}{|c|}{ Dose (mM) } & \multicolumn{3}{|c|}{ Anova } & \multirow[t]{2}{*}{ Experiment } \\
\hline Compound & 0 & 0.125 & 0.25 & 0.5 & 1 & F-ratio & p & \\
\hline $1 \dagger$ & $\begin{array}{c}1.00 \pm 0.04 \\
? \mathrm{~A}, \mathrm{a} ?\end{array}$ & $\begin{array}{c}0.97 \pm 0.04 \\
\text { A,b }\end{array}$ & $\begin{array}{c}0.68 \pm 0.03 \\
\mathrm{C}, \mathrm{bc}\end{array}$ & $\begin{array}{c}0.36 \pm 0.04 \\
\mathrm{C}, \mathrm{c}\end{array}$ & $0 \neq$ & 58.3 & $1.6 \mathrm{e}-18$ & $1-4$ \\
\hline $3 a$ & $\begin{array}{c}1.00 \pm 0.04 \\
\mathrm{~A}, \mathrm{a}\end{array}$ & $\begin{array}{c}0.97 \pm 0.06 \\
\text { A,a }\end{array}$ & $\begin{array}{c}1.07 \pm 0.07 \\
\mathrm{~A}, \mathrm{a}\end{array}$ & $\begin{array}{c}1.08 \pm 0.08 \\
\mathrm{~A}, \mathrm{a}\end{array}$ & $\begin{array}{c}1.00 \pm 0.07 \\
\mathrm{~A}, \mathrm{a}\end{array}$ & 1.4 & 0.23 (ns) & 1 \\
\hline $3 b$ & $\begin{array}{c}1.00 \pm 0.04 \\
\mathrm{~A}, \mathrm{a}\end{array}$ & $\begin{array}{c}0.60 \pm 0.04 \\
\mathrm{~A}, \mathrm{~b}\end{array}$ & $0^{\ddagger}$ & 0f & $0 \ddagger$ & 51.8 & 3.3 e- 9 & 2 \\
\hline $3 c$ & $\begin{array}{c}1.00 \pm 0.03 \\
\mathrm{~A}\end{array}$ & $0^{\ddagger}$ & $0^{\ddagger}$ & $0^{\ddagger}$ & $0^{\ddagger}$ & $\mathrm{na}^{\S}$ & $\mathrm{na}^{\S}$ & 1 \\
\hline 16 & $\begin{array}{c}1.00 \pm 0.04 \\
\mathrm{~A}, \mathrm{a}\end{array}$ & $\begin{array}{c}0.56 \pm 0.05 \\
\mathrm{~A}, \mathrm{~b}\end{array}$ & $0^{\ddagger}$ & $0^{\ddagger}$ & $0^{\ddagger}$ & 40.4 & $7.8 \mathrm{e}-8$ & 3 \\
\hline 17 & $\begin{array}{c}1.00 \pm 0.04 \\
\mathrm{~A}, \mathrm{a}\end{array}$ & $\begin{array}{c}0.69 \pm 0.04 \\
\mathrm{~A}, \mathrm{~b}\end{array}$ & $\begin{array}{c}0.68 \pm 0.04 \\
\text { C,b }\end{array}$ & $\begin{array}{c}0.61 \pm 0.04 \\
\mathrm{BC}, \mathrm{b}\end{array}$ & $0^{\ddagger}$ & 19.0 & 4.4 e- 9 & 2 \\
\hline 18 & $\begin{array}{c}1.00 \pm 0.04 \\
\mathrm{~A}, \mathrm{a}\end{array}$ & $\begin{array}{c}0.85 \pm 0.04 \\
\mathrm{AB}, \mathrm{ab}\end{array}$ & $\begin{array}{c}0.85 \pm 0.03 \\
\mathrm{BC}, \mathrm{ab}\end{array}$ & $\begin{array}{c}0.64 \pm 0.04 \\
\mathrm{~B}, \mathrm{c}\end{array}$ & $\begin{array}{c}0.28 \pm 0.02 \\
\mathrm{~B}, \mathrm{~d}\end{array}$ & 27.8 & $1.8 \mathrm{e}-15$ & 4 \\
\hline 19 & $\begin{array}{c}1.00 \pm 0.06 \\
\mathrm{~A}, \mathrm{a}\end{array}$ & $\begin{array}{c}0.75 \pm 0.05 \\
\quad \mathrm{BC}, \mathrm{b}\end{array}$ & $\begin{array}{c}0.46 \pm 0.06 \\
\mathrm{D}, \mathrm{c}\end{array}$ & $\begin{array}{c}0.38 \pm 0.05 \\
\mathrm{C}, \mathrm{c}\end{array}$ & $0^{\ddagger}$ & 68.5 & $2.3 \mathrm{e}-23$ & 4 \\
\hline 20 & $\begin{array}{c}1.00 \pm 0.04 \\
\mathrm{~A}, \mathrm{a}\end{array}$ & $\begin{array}{c}0.90 \pm 0.04 \\
\mathrm{AB}, \mathrm{a}\end{array}$ & $\begin{array}{c}0.71 \pm 0.05 \\
\mathrm{C}, \mathrm{b}\end{array}$ & $\begin{array}{c}0.70 \pm 0.04 \\
\mathrm{~B}, \mathrm{~b}\end{array}$ & $\begin{array}{c}0.56 \pm 0.05 \\
\mathrm{~B}, \mathrm{~b}\end{array}$ & 16.0 & $1.6 \mathrm{e}-10$ & 3 \\
\hline $\begin{array}{l}\text { Anova } \\
\text { F-ratio }\end{array}$ & $\mathrm{na}^{\S}$ & 12.0 & 27.6 & 26.5 & 22.8 & & & \\
\hline $\mathbf{p}$ & $\mathrm{na}^{\S}$ & $1.6 \mathrm{e}-12$ & 7.2 e- 19 & $2.9 \mathrm{e}-20$ & $1.1 \mathrm{e}-10$ & & & \\
\hline
\end{tabular}

$\dagger 1$ was the repeated control condition for all experiments; presented data are that of all grouped experiments. See text for interexperiment statistics.

$\ddagger 0$ is no survivor at day 7

$\S$ not applicable

\section{Experimental}

\section{General}


Reagents and solvents were supplied by Aldrich, Acros, Lancaster, Alfa Aesar, Fluka or TCI and purchased at the highest commercial quality to be used without further purification. NMR spectra were recorded on a Bruker $300\left({ }^{1} \mathrm{H}: 300 \mathrm{MHz} ;{ }^{13} \mathrm{C}: 75\right.$ $\mathrm{MHz})$, Bruker $400\left({ }^{1} \mathrm{H}: 400 \mathrm{MHz} ;{ }^{13} \mathrm{C}: 100 \mathrm{MHz}\right)$, or Bruker $500\left({ }^{1} \mathrm{H}: 500 \mathrm{MHz} ;{ }^{13} \mathrm{C}: 125 \mathrm{MHz}\right)$ spectrometers, at 295-298K, using $\mathrm{CDCl}_{3}, \mathrm{CD}_{3} \mathrm{OD}$ or $\mathrm{D}_{2} \mathrm{O}$ as solvents. The chemical shifts $(\delta \mathrm{ppm})$ are referenced to the solvent residual peak and coupling constants $J$ in $\mathrm{Hz}$ are reported in the standard fashion. The following abbreviations are used to explain the multiplicities: $\mathrm{s}=\mathrm{singlet}, \mathrm{d}=\mathrm{doublet}, \mathrm{t}$ = triplet, $\mathrm{q}=$ quartet, quint. = quintuplet, sext. = sextuplet, hept. = heptuplet, $\mathrm{m}=$ multiplet, $\mathrm{br}=$ broad; Ar is used for Aromatic and for the assignment of ${ }^{13} \mathrm{C}$ carbon signals : $\mathrm{C}_{\mathrm{q}}=$ quaternary carbon. Electrospray ionization (ESI) mass spectrometry (MS) experiments were performed on a Thermo Finnigan LCQ Advantage mass. High-resolution mass spectra (HRMS) were recorded on a Finnigan Mat 95xL mass spectrometer using electrospray. Analytical thin-layer chromatography was carried out on silica gel Merck 60 D254 $(0.25 \mathrm{~mm})$. Flash chromatography was performed on Merck Si 60 silica gel $(40-63 \mu \mathrm{m})$. Infra-red (IR) spectra were recorded with a IRAffinity-1 Shimadzu spectrometer using Attenuated Total Reflectance (ATRMiracle), and the wavenumbers are expressed in $\mathrm{cm}^{-1}$. Optical rotations were measured on a Perkin Elmer 241 or Jasco P1010 polarimeter with a $10 \mathrm{~cm}$ cell (concentration c expressed in $\mathrm{g} / 100 \mathrm{~mL}$ ). Melting points were measured using Büchi apparatus B-540. All data for chlorogenic acids or related derivatives presented in this paper use the recommended IUPAC numbering system. The assignment of NMR signals has been made according to the numbering shown in the general structures below (Figure 6). ${ }^{37}$

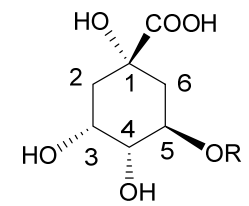

Figure 6 : Numbering for CQA and deoxy analogs

\section{Synthetic procedures}

General procedures for the preparation of monoesters 5-7a and $\mathbf{b}$.

Conditions A : To a solution of triol $4^{24}$ in DMF / pyridine $(\mathrm{v} / \mathrm{v} 3 / 2, \mathrm{c}=0.4 \mathrm{M})$ under nitrogen, was added the appropriate acetylated hydroxycinnamoyl chloride (1.5 equiv.) and the mixture was heated at $45^{\circ} \mathrm{C}$ under stirring until a maximum of conversion was reached. Methanol was added and after $15 \mathrm{~min}$ under stirring, the resulting mixture was concentrated, diluted with EtOAc, washed with $1 \mathrm{M} \mathrm{HCl}$ then with a saturated $\mathrm{NaHCO}_{3}$ solution then with brine. The organic layer was dried over $\mathrm{Na}_{2} \mathrm{SO}_{4}, \mathrm{concentrated}$ and purified by flash chromatography on silica using the appropriate eluent.

Conditions B : Same procedure as above replacing solvents by dichloromethane / pyridine (v/v 5/1, c = 0.1M) and adding DMAP ( $20 \%$ mol.). The acetylated hydroxycinnamoyl chloride was added at a temperature between $-18^{\circ} \mathrm{C}$ and $0^{\circ} \mathrm{C}$ then the mixture was stirred cooling up to room temperature until a maximum of conversion was reached. The work-up and isolation procedures are identical.

5a $\left(\right.$ EtOAc $/$ petroleum ether $=1 / 1$ to 3/1, second fraction, light yellow oil, 15\%)), $[\alpha]_{D}^{25}-5.8\left(c 0.89\right.$ in $\left.\mathrm{CH}_{2} \mathrm{Cl}_{2}\right)$; IR(ATR) 2934, 1763, 1736, 1707, 1638, 1601, 1508, $1456 \mathrm{~cm}^{-1} ;{ }^{1} \mathrm{H}$ NMR (400 MHz, 298K, $\left.\mathrm{CDCl}_{3}\right) \delta 7.58\left(\mathrm{~d}, 1 \mathrm{H},{ }^{3} \mathrm{~J} 16.0 \mathrm{~Hz}, \mathrm{CH}=\mathrm{CHCO}\right), 7.08-$ $7.05\left(\mathrm{~m}, 2 \mathrm{H}, \mathrm{H}_{\mathrm{Ar}}\right), 7.00\left(\mathrm{~d}, 1 \mathrm{H}, J_{\text {ortho }} 8.6 \mathrm{~Hz}, \mathrm{H}_{\mathrm{Ar}}\right), 6.31\left(\mathrm{~d}, 1 \mathrm{H},{ }^{3} \mathrm{~J} 16.0 \mathrm{~Hz}, \mathrm{CH}=\mathrm{CHCO}\right), 5.51\left(\mathrm{tt}, 1 \mathrm{H},{ }^{3} \mathrm{~J} 11.2 \mathrm{~Hz},{ }^{3} \mathrm{~J} 4.4 \mathrm{~Hz}, \mathrm{H}_{5}\right), 4.43$ (s, $\left.1 \mathrm{H}, \underline{\mathrm{O}}_{1}\right), 4.32\left(\mathrm{~m}, 1 \mathrm{H}, \mathrm{H}_{3}\right), 3.98\left(\mathrm{~m}, 1 \mathrm{H}, \mathrm{O}_{3}\right), 3.82\left(\mathrm{~s}, 3 \mathrm{H}, \mathrm{COOC} \underline{H}_{3}\right), 3.74\left(\mathrm{~s}, 3 \mathrm{H}, \mathrm{OC}_{3}\right), 2.47-2.29\left(\mathrm{~m}, 2 \mathrm{H}, \mathrm{H}_{4}\right.$ and $\left.\mathrm{H}_{6}\right), 2.27$ (s, 3H, OCOCH 3 ), $2.04-1.99\left(\mathrm{~m}, 2 \mathrm{H}, 2 \mathrm{xH}_{2}\right), 1.91\left(\mathrm{dd}, 1 \mathrm{H},{ }^{2} \mathrm{~J} 12.6 \mathrm{~Hz},{ }^{3} \mathrm{~J} 11.2 \mathrm{~Hz}, \mathrm{H}_{6 \mathrm{a}}\right), 1.65\left(\mathrm{ddd}, 1 \mathrm{H},{ }^{2} \mathrm{~J} 12.7 \mathrm{~Hz},{ }^{3} \mathrm{~J} 11.5 \mathrm{~Hz},{ }^{3} \mathrm{~J} 3.0\right.$ $\left.\mathrm{Hz}, \mathrm{H}_{4 \mathrm{a}}\right) ;{ }^{13} \mathrm{C}$ NMR $\left(100 \mathrm{MHz}, 298 \mathrm{~K}, \mathrm{CDCl}_{3}\right) \delta=174.7\left(\underline{\mathrm{COOCH}}_{3}\right), 168.8\left(\mathrm{OCOCH}_{3}\right), 166.0(\mathrm{CH}=\mathrm{CHCO}), 151.4\left(\mathrm{C}_{\mathrm{q}} \mathrm{Ar}\right), 144.3$ $(\underline{\mathrm{CH}}=\mathrm{CHCO}), 141.4\left(\mathrm{C}_{\mathrm{q} \mathrm{Ar}}\right), 133.3\left(\mathrm{C}_{\mathrm{q}} \mathrm{Ar}\right), 123.2\left(\mathrm{CH}_{\mathrm{Ar}}\right), 121.2\left(\mathrm{CH}_{\mathrm{Ar}}\right), 118.3(\mathrm{CH}=\underline{\mathrm{CHCO}}), 111.3\left(\mathrm{CH}_{\mathrm{Ar}}\right), 76.2\left(\mathrm{C}_{1}\right), 67.4\left(\mathrm{C}_{3}\right), 66.7$ $\left(\mathrm{C}_{5}\right), 55.9\left(\mathrm{OCH}_{3}\right), 53.0\left(\mathrm{COOCH}_{3}\right), 39.7\left(\mathrm{C}_{6}\right), 38.1\left(\mathrm{C}_{4}\right), 38.0\left(\mathrm{C}_{2}\right), 20.6\left(\mathrm{OCOCH}_{3}\right) ; \mathrm{HRMS}(\mathrm{ESI})$ : calcd for $\mathrm{C}_{20} \mathrm{H}_{24} \mathrm{NaO}_{9}\left[\mathrm{M}+\mathrm{Na}^{+}\right]$: 431.1313, found: 431.1332 .

5b $\left(\right.$ EtOAc $/$ petroleum ether $=1 / 1$ to $3 / 1$, light yellow oil, 33\%), $[\alpha]_{\mathrm{D}}^{25}+3.3\left(c 0.81\right.$ in $\left.\mathrm{CH}_{3} \mathrm{OH}\right)$; IR(ATR) 3443, 2951, 2926, 1763, 1732, 1705, 1634, 1599, 1510, $1454 \mathrm{~cm}^{-1}$; ${ }^{1} \mathrm{H}$ NMR (400 MHz, 298K, $\left.\mathrm{CDCl}_{3}\right) \delta 7.64\left(\mathrm{~d}, 1 \mathrm{H},{ }^{3} \mathrm{~J} 15.9 \mathrm{~Hz}, \mathrm{C} \underline{\mathrm{H}}=\mathrm{CHCO}\right), 7.12-$ $7.04\left(\mathrm{~m}, 3 \mathrm{H}, \mathrm{H}_{\mathrm{Ar}}\right), 6.37\left(\mathrm{~d}, 1 \mathrm{H},{ }^{3} \mathrm{~J} 16.0 \mathrm{~Hz}, \mathrm{CH}=\mathrm{CHCO}\right), 5.44\left(\mathrm{~m}, 1 \mathrm{H},{ }^{3} \mathrm{~J} 3.9 \mathrm{~Hz}, \mathrm{H}_{3}\right), 4.38\left(\mathrm{tt}, 1 \mathrm{H},{ }^{3} \mathrm{~J} 10.2 \mathrm{~Hz},{ }^{3} \mathrm{~J} 4.1 \mathrm{~Hz}, \mathrm{H}_{5}\right), 3.87(\mathrm{~s}$, $\left.3 \mathrm{H}, \mathrm{OC}_{3}\right), 3.82\left(\mathrm{~s}, 3 \mathrm{H}, \mathrm{COOC}_{3}\right), 2.32\left(\mathrm{~s}, 3 \mathrm{H}, \mathrm{OCOC}_{3}\right), 2.26\left(\mathrm{~m}, 1 \mathrm{H}, \mathrm{H}_{4}\right), 2.15-2.07\left(\mathrm{~m}, 2 \mathrm{H}, \mathrm{H}_{2}\right.$ and $\left.\mathrm{H}_{6}\right), 2.02\left(\mathrm{~m}, 1 \mathrm{H}, \mathrm{H}_{2}\right), 1.90$ $\left(\mathrm{dd}, 1 \mathrm{H},{ }^{2} \mathrm{~J} 12.9 \mathrm{~Hz},{ }^{3} \mathrm{~J} 10.1 \mathrm{~Hz}, \mathrm{H}_{6 \mathrm{a}}\right), 1.71\left(\mathrm{ddd}, 1 \mathrm{H},{ }^{2} \mathrm{~J} 13.6 \mathrm{~Hz},{ }^{3} \mathrm{~J} 10.3 \mathrm{~Hz},{ }^{3} J 3.4 \mathrm{~Hz}, \mathrm{H}_{4 \mathrm{a}}\right) ;{ }^{13} \mathrm{C} \mathrm{NMR}\left(100 \mathrm{MHz}, 298 \mathrm{~K}, \mathrm{CDCl}_{3}\right) \delta=$ $175.8\left(\underline{\mathrm{COOCH}}_{3}\right), 168.9\left(\mathrm{O}_{\underline{C O C H}}\right), 166.1(\mathrm{CH}=\mathrm{CHCO}), 151.5\left(\mathrm{C}_{\mathrm{q} \mathrm{Ar}}\right), 144.7(\underline{\mathrm{C} H}=\mathrm{CHCO}), 141.6\left(\mathrm{C}_{\mathrm{q}} \mathrm{Ar}\right), 133.4\left(\mathrm{C}_{\mathrm{q} A r}\right), 123.4(\mathrm{CH} \mathrm{Ar})$, 121.6 $\left(\mathrm{CH}_{\mathrm{Ar}}\right), 118.4(\mathrm{CH}=\underline{\mathrm{CHCO}}), 111.3\left(\mathrm{CH}_{\mathrm{Ar}}\right), 75.2\left(\mathrm{C}_{1}\right), 69.5\left(\mathrm{C}_{3}\right), 63.5\left(\mathrm{C}_{5}\right), 56.1\left(\mathrm{O}_{\underline{C}}\right), 53.4\left(\mathrm{COO}_{3} \mathrm{H}_{3}\right), 43.1\left(\mathrm{C}_{6}\right), 38.5\left(\mathrm{C}_{4}\right)$, $37.1\left(\mathrm{C}_{2}\right), 20.7\left(\mathrm{OCO}^{-} \mathrm{H}_{3}\right)$; HRMS (ESI): calcd for $\mathrm{C}_{20} \mathrm{H}_{24} \mathrm{NaO}_{9}\left[\mathrm{M}+\mathrm{Na}^{+}\right]$: 431.1313, found: 431.1298 . 
6a $\left(\right.$ EtOAc $/$ petroleum ether $=1 / 1$ to 3/1, light yellow oil, 19\%), $[\alpha]_{\mathrm{D}}^{25}+3.6\left(c 1.03\right.$ in $\left.\mathrm{CH}_{2} \mathrm{Cl}_{2}\right)$; IR(ATR) 1765, 1736, 1709, 1638, 1506, $1435 \mathrm{~cm}^{-1}$; ${ }^{1} \mathrm{H}$ NMR (400 MHz, 298K, $\left.\mathrm{CDCl}_{3}\right) \delta 7.63\left(\mathrm{~d}, 1 \mathrm{H},{ }^{3} \mathrm{~J} 16.0 \mathrm{~Hz}, \mathrm{CH}=\mathrm{CHCO}\right), 7.51$ and $7.01\left(2 \mathrm{~d}, 2 \mathrm{x} 2 \mathrm{H},{ }^{3} \mathrm{~J} 8.0 \mathrm{~Hz}\right.$, $\left.\mathrm{H}_{\mathrm{Ar}}\right), 6.33\left(\mathrm{~d}, 1 \mathrm{H},{ }^{3} \mathrm{~J} 16.0 \mathrm{~Hz}, \mathrm{CH}=\mathrm{C} \underline{\mathrm{HCO}}\right), 5.53\left(\mathrm{tt}, 1 \mathrm{H},{ }^{2} \mathrm{~J} 11.3 \mathrm{~Hz},{ }^{3} \mathrm{~J} 4.4 \mathrm{~Hz}, \mathrm{H}_{5}\right), 4.33\left(\mathrm{~m}, 1 \mathrm{H},{ }^{3} \mathrm{~J} 3.3 \mathrm{~Hz}, \mathrm{H}_{3}\right), 3.84(\mathrm{~s}, 1 \mathrm{H}, \mathrm{O} \underline{\mathrm{H}}), 3.78$ (s, 3H, COOCH$\left.\underline{H}_{3}\right), 2.36\left(\mathrm{~m}, 2 \mathrm{H}, \mathrm{H}_{4}\right.$ and $\left.\mathrm{H}_{6}\right), 2.29$, (s, 3H, OCOCH$\left.\underline{H}_{3}\right), 2.00\left(\mathrm{~m}, 2 \mathrm{H}, \mathrm{H}_{2}\right), 1.90\left(\mathrm{dd}, 1 \mathrm{H},{ }^{2} \mathrm{~J} \approx^{3} \mathrm{~J} 11.5 \mathrm{~Hz}, \mathrm{H}_{6 \mathrm{a}}\right), 1.67(\mathrm{ddd}$, $\left.1 \mathrm{H},{ }^{2} \mathrm{~J} 13.6 \mathrm{~Hz},{ }^{3} \mathrm{~J} 10.3 \mathrm{~Hz},{ }^{3} \mathrm{~J} 3.4 \mathrm{~Hz}, \mathrm{H}_{4 \mathrm{a}}\right) ;{ }^{13} \mathrm{C} \mathrm{NMR}\left(100 \mathrm{MHz}, 298 \mathrm{~K}, \mathrm{CDCl}_{3}\right)$ with traces of $\mathbf{6 b}$ or $\mathbf{6 c} \delta 175.0\left(\mathrm{COOCH}_{3}\right), 169.3$ $\left.\left(\mathrm{OCOCH}_{3}\right), 166.1(\mathrm{CH}=\mathrm{CHCO}), 152.2\left(\mathrm{C}_{\mathrm{q}} \mathrm{Ar}\right), 144.0(\underline{\mathrm{CH}}=\mathrm{CHCO}), 132.1\left(\mathrm{C}_{\mathrm{q} \mathrm{Ar}}\right), 129.3\left(\mathrm{CH}_{\mathrm{Ar}}\right), 122.2(\mathrm{CH})_{\mathrm{Ar}}\right), 118.3(\mathrm{CH}=\underline{\mathrm{CHCO}})$,

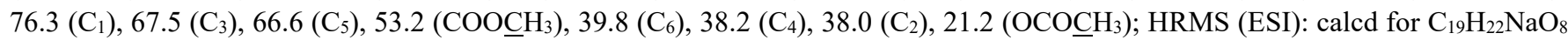
$\left[\mathrm{M}+\mathrm{Na}^{+}\right]:$401.1207, found: 401.1196 .

6b (EtOAc / petroleum ether $=1 / 1$ to 3/1, light yellow oil, 28\%), $[\alpha]_{\mathrm{D}}^{25}+27.8\left(c\right.$ 0.97, $\left.\mathrm{CH}_{2} \mathrm{Cl}_{2}\right)$; IR(ATR) 3406, 2947, 1759, 1724, 1680, 1634, 1601, 1508, $1446 \mathrm{~cm}^{-1}$; ${ }^{1} \mathrm{H}$ NMR $\left(400 \mathrm{MHz}, 295 \mathrm{~K}, \mathrm{CDCl}_{3}\right) \delta=7.65\left(\mathrm{~d}, 1 \mathrm{H},{ }^{3} \mathrm{~J} 16.0 \mathrm{~Hz}, \mathrm{C} \underline{\mathrm{H}}=\mathrm{CHCO}\right), 7.52 \mathrm{and} 7.11(2 \mathrm{~d}$, $\left.2 \mathrm{x} 2 \mathrm{H},{ }^{3} \mathrm{~J} 8.0 \mathrm{~Hz}, \mathrm{H}_{\mathrm{Ar}}\right), 6.37\left(\mathrm{~d}, 1 \mathrm{H},{ }^{3} \mathrm{~J} 16.0 \mathrm{~Hz}, \mathrm{CH}=\mathrm{C} \underline{\mathrm{HCO}}\right), 5.42\left(\mathrm{~m}, 1 \mathrm{H},{ }^{3} \mathrm{~J} 3.9 \mathrm{~Hz}, \mathrm{H}_{3}\right), 4.36\left(\mathrm{tt}, 1 \mathrm{H},{ }^{3} \mathrm{~J} 10.1 \mathrm{~Hz},{ }^{3} \mathrm{~J} 4.0 \mathrm{~Hz}, \mathrm{H}_{5}\right), 3.80$ (s, 3H, COOCH 3 ), $2.30\left(\mathrm{~s}, 3 \mathrm{H}, \mathrm{OCOC}_{3}\right), 2.22\left(\mathrm{~m}, 1 \mathrm{H}, \mathrm{H}_{4}\right), 2.16-2.00\left(\mathrm{~m}, 3 \mathrm{H}, 2 \mathrm{xH}_{2}\right.$ and $\left.\mathrm{H}_{6}\right), 1.90\left(\mathrm{dd}, 1 \mathrm{H},{ }^{2} \mathrm{~J} 13.0 \mathrm{~Hz},{ }^{3} \mathrm{~J} 9.9 \mathrm{~Hz}\right.$, $\left.\mathrm{H}_{6 \mathrm{a}}\right), 1.71\left(\mathrm{ddd}, 1 \mathrm{H},{ }^{2} \mathrm{~J} 13.6 \mathrm{~Hz},{ }^{3} \mathrm{~J} 10.2 \mathrm{~Hz},{ }^{3} \mathrm{~J} 3.4 \mathrm{~Hz}, \mathrm{H}_{4}\right) ;{ }^{13} \mathrm{C} \mathrm{NMR}\left(100 \mathrm{MHz}, 295 \mathrm{~K}, \mathrm{CDCl}_{3}\right) \delta=175.8\left(\underline{\mathrm{COOCH}}_{3}\right), 169.3$ $\left(\mathrm{O}_{\underline{C O C H}}\right), 166.2(\mathrm{CH}=\mathrm{CH} \underline{C O}), 152.2\left(\mathrm{C}_{\mathrm{q}} \mathrm{Ar}\right), 144.2(\underline{\mathrm{CH}}=\mathrm{CHCO}), 132.1\left(\mathrm{C}_{\mathrm{q}} \mathrm{Ar}\right), 129.4\left(\mathrm{CH}_{\mathrm{Ar}}\right), 122.2\left(\mathrm{CH}{ }_{\mathrm{Ar}}\right), 118.4(\mathrm{CH}=\underline{\mathrm{CHCO}})$,

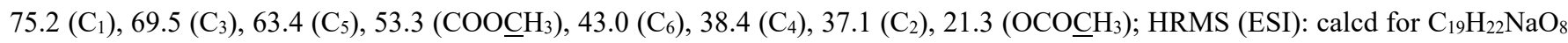
$\left[\mathrm{M}+\mathrm{Na}^{+}\right]:$401.1207, found: 401.1197 .

$7 \mathbf{a}$ (diethyl ether/ dichoromethane $=1 / 10$ to $1 / 4$, light yellow oil, $11 \%$ ), $[\alpha]_{\mathrm{D}}^{25}+6.5\left(c 1.22\right.$ in $\left.\mathrm{CH}_{2} \mathrm{Cl}_{2}\right)$; IR(ATR) 1770, 1736, 1711, 1639, $1504 \mathrm{~cm}^{-1}$; ${ }^{1} \mathrm{H}$ NMR $\left(400 \mathrm{MHz}, 296 \mathrm{~K}, \mathrm{CDCl}_{3}\right) \delta 7.58\left(\mathrm{~d}, 1 \mathrm{H},{ }^{3} \mathrm{~J} 16.0 \mathrm{~Hz}, \mathrm{C} \underline{\mathrm{H}}=\mathrm{CHCO}\right), 7.39-7.33\left(\mathrm{~m}, 2 \mathrm{H}, \mathrm{H}_{\mathrm{Ar}}\right), 7.19(\mathrm{~d}, 1 \mathrm{H}$, $\left.J_{\text {ortho }} 8.3 \mathrm{~Hz}, \mathrm{H}_{\mathrm{Ar}}\right), 6.32\left(\mathrm{~d}, 1 \mathrm{H},{ }^{3} \mathrm{~J} 16.0 \mathrm{~Hz}, \mathrm{CH}=\mathrm{CHCO}\right), 5.51\left(\mathrm{tt},{ }^{3} \mathrm{~J} 11.4 \mathrm{~Hz},{ }^{3} \mathrm{~J} 4.4 \mathrm{~Hz}, 1 \mathrm{H}, \mathrm{H}_{5}\right), 4.32\left(\mathrm{~s}, 1 \mathrm{H}, \mathrm{H}_{3}\right), 4.32 \mathrm{and} 3.88(2 \mathrm{~m}$, $2 \mathrm{H}, \mathrm{O}_{1}$ and $\left.\mathrm{OH}_{3}\right), 3.77\left(\mathrm{~s}, 3 \mathrm{H}, \mathrm{COOC} \underline{H}_{3}\right), 2.39-2.27\left(\mathrm{~m}, 8 \mathrm{H}, \mathrm{H}_{4}, \mathrm{H}_{6}\right.$ and $\left.2 \mathrm{xOCOC}_{3}\right), 2.00\left(\mathrm{~m}, 2 \mathrm{H}, 2 \mathrm{HH}_{2}\right), 1.88\left(\mathrm{dd}, 1 \mathrm{H},{ }^{2} J \approx^{3} \mathrm{~J} 11.5\right.$ $\left.\mathrm{Hz}, \mathrm{H}_{6 \mathrm{a}}\right), 1.65$ (ddd, $\left.1 \mathrm{H},{ }^{2} J 13.6 \mathrm{~Hz},{ }^{3} \mathrm{~J} 10.2 \mathrm{~Hz},{ }^{3} \mathrm{~J} 3.4 \mathrm{~Hz}, \mathrm{H}_{4}\right) ;{ }^{13} \mathrm{C} \mathrm{NMR}\left(100 \mathrm{MHz}, 297 \mathrm{~K}, \mathrm{CDCl}_{3}\right) \delta 174.9\left(\mathrm{COOCH}_{3}\right), 168.2 \mathrm{and}$ $168.1\left(2 \mathrm{xOCOCH}_{3}\right), 165.9(\mathrm{CH}=\mathrm{CHCO}), 143.6\left(\mathrm{C}_{\mathrm{q}} \mathrm{Ar}\right), 143.1(\underline{\mathrm{CH}}=\mathrm{CHCO}), 142.5$ and $133.3\left(\mathrm{C}_{\mathrm{q}} \mathrm{Ar}\right), 126.5,124.0$ and $122.8\left(\mathrm{CH}_{\mathrm{Ar}}\right)$, $119.3(\mathrm{CH}=\underline{\mathrm{C} H C O}), 76.3\left(\mathrm{C}_{1}\right), 67.5\left(\mathrm{C}_{3}\right), 66.8\left(\mathrm{C}_{5}\right), 53.2\left(\mathrm{COOCH}_{3}\right), 39.7\left(\mathrm{C}_{6}\right), 38.1\left(\mathrm{C}_{4}\right), 38.0\left(\mathrm{C}_{2}\right), 20.71\left(2 \times \mathrm{xCOCH}_{3}\right)$; HRMS (ESI): calcd for $\mathrm{C}_{21} \mathrm{H}_{24} \mathrm{NaO}_{10}\left[\mathrm{M}+\mathrm{Na}^{+}\right]$: 459.1262, found: 459.1251 .

7b (diethyl ether/ dichoromethane $=1 / 10$ to $1 / 4$, light yellow oil, $34 \%$ ) $[\alpha]_{\mathrm{D}}^{25}+24.7\left(c 0.93\right.$ in $\left.\mathrm{CH}_{2} \mathrm{Cl}_{2}\right)$; IR(ATR) 1773, 1732, 1707, 1639, $1504 \mathrm{~cm}^{-1}$; ${ }^{1} \mathrm{H}$ NMR $\left(400 \mathrm{MHz}, 296 \mathrm{~K}, \mathrm{CDCl}_{3}\right)$ probably contaminated with $7 \mathbf{a}$ and $7 \mathbf{c} \delta 7.60\left(\mathrm{~d}, 1 \mathrm{H},{ }^{3} \mathrm{~J} 16.0 \mathrm{~Hz}, \mathrm{CH}=\mathrm{CHCO}\right)$, $7.41-7.34\left(\mathrm{~m}, 2 \mathrm{H}, \mathrm{H}_{\mathrm{Ar}}\right), 7.20\left(\mathrm{~d}, 1 \mathrm{H}, J_{\text {ortho }} 8.3 \mathrm{~Hz}, \mathrm{H}_{\mathrm{Ar}}\right), 6.36\left(\mathrm{~d}, 1 \mathrm{H},{ }^{3} \mathrm{~J} 16.0 \mathrm{~Hz}, \mathrm{CH}=\mathrm{C} \underline{\mathrm{HCO}}\right), 5.40\left(\mathrm{~m}, 1 \mathrm{H},{ }^{3} \mathrm{~J} 3.9 \mathrm{~Hz}, \mathrm{H}_{3}\right), 4.34(\mathrm{~m}$, $\left.1 \mathrm{H}, \mathrm{H}_{5}\right), 3.78\left(\mathrm{~s}, 3 \mathrm{H}, \mathrm{COOC} \underline{\mathrm{H}}_{3}\right), 3.23(\mathrm{~m}, 1 \mathrm{H}, \mathrm{OH}-1$ or OH-5$), 2.29$ and $2.28\left(2 \mathrm{~s}, 6 \mathrm{H}, 2 \mathrm{xOCOC}_{3}\right), 2.22-1.98\left(\mathrm{~m}, 4 \mathrm{H}, \mathrm{H}_{2}, \mathrm{H}_{4}\right.$ and $/ \mathrm{or}^{\circ}$ $\left.\mathrm{H}_{6}\right), 1.89$ (dd, $\left.1 \mathrm{H},{ }^{2} J 12.9 \mathrm{~Hz},{ }^{3} \mathrm{~J} 10.0 \mathrm{~Hz}, \mathrm{H}_{6 \mathrm{a}}\right), 1.69$ (ddd, $\left.1 \mathrm{H},{ }^{2} J 13.6 \mathrm{~Hz},{ }^{3} \mathrm{~J} 10.2 \mathrm{~Hz},{ }^{3} \mathrm{~J} 3.3 \mathrm{~Hz}, \mathrm{H}_{4 \mathrm{a}}\right) ;{ }^{13} \mathrm{C} \mathrm{NMR}(100 \mathrm{MHz}, 297 \mathrm{~K}$, $\left.\mathrm{CDCl}_{3}\right) \delta 175.7\left(\underline{\mathrm{COOCH}}_{3}\right), 168.2$ and $168.1\left(2 \mathrm{xOCOCH}_{3}\right), 165.9(\mathrm{CH}=\mathrm{CHCO}), 143.5\left(\mathrm{C}_{\mathrm{q} \mathrm{Ar}}\right), 143.3(\underline{\mathrm{CH}}=\mathrm{CHCO}), 142.4(\mathrm{C} q \mathrm{Ar})$, $133.2\left(\mathrm{C}_{\mathrm{q} \mathrm{Ar}}\right), 126.5\left(\mathrm{CH}_{\mathrm{Ar}}\right), 124.0\left(\mathrm{CH}_{\mathrm{Ar}}\right), 122.9\left(\mathrm{CH}_{\mathrm{Ar}}\right), 119.4(\mathrm{CH}=\underline{\mathrm{C} H C O}), 75.1\left(\mathrm{C}_{1}\right), 69.5\left(\mathrm{C}_{3}\right), 63.2\left(\mathrm{C}_{5}\right), 53.1\left(\mathrm{COOCH}_{3}\right), 42.8$ (C6), $38.2\left(\mathrm{C}_{4}\right), 36.9\left(\mathrm{C}_{2}\right), 20.7\left(2 \mathrm{xOCOCH}_{3}\right)$; HRMS (ESI): calcd for $\overline{\mathrm{C}}_{21} \mathrm{H}_{24} \mathrm{NaO}_{10}\left[\mathrm{M}+\mathrm{Na}^{+}\right]$: 459.1262 , found: 459.1253.

General procedures for the preparation of diesters 9-13. Conditions A : Same procedure as Conditions A for the synthesis of monoesters using 2 equiv. of the appropriate acetylated hydroxycinnamoyl chloride 8a, $\mathbf{b}$ or $\mathbf{c}$. Conditions B : Same procedure as Conditions $\mathrm{C}$ for the synthesis of monoesters with an addition at $0^{\circ} \mathrm{C}$ and a reaction at room temperature. Conditions $\mathbf{C}:$ Same procedure as Conditions B for the synthesis of monoesters using 2 equiv. of the appropriate acetylated hydroxycinnamoyl chloride $\mathbf{8 a}$, b or $\mathbf{c}$.

$9\left(\right.$ EtOAc/ Pentane $=1 / 1$ to $2 / 1$, white solid, 43\%), mp: $86-87^{\circ} \mathrm{C},[\alpha]_{\mathrm{D}}^{25}-74.7\left(c 0.95\right.$ in $\left.\mathrm{CH}_{2} \mathrm{Cl}_{2}\right)$; IR(ATR) 1765, 1732, 1709, 1638, 1601, $1506 \mathrm{~cm}^{-1} ;{ }^{1} \mathrm{H}$ NMR (400 MHz, 295K, $\left.\mathrm{CDCl}_{3}\right) \delta 7.69$ and $7.62\left(2 \mathrm{~d}, 2 \mathrm{H},{ }^{3} J 16.0 \mathrm{~Hz}, \mathrm{C} \underline{\mathrm{H}}=\mathrm{CHCO}\right), 7.55$ (d, $2 \mathrm{H}, J$ ortho 8.3 $\left.\mathrm{Hz}, \mathrm{H}_{\mathrm{Ar}}\right), 7.14-7.04\left(\mathrm{~m}, 5 \mathrm{H}, \mathrm{H}_{\mathrm{Ar}}\right), 6.42$ and $6.34\left(2 \mathrm{~d},{ }^{2} \mathrm{H},{ }^{3} \mathrm{~J} 16.0 \mathrm{~Hz}, \mathrm{CH}=\mathrm{CHCO}\right), 5.58-5.50\left(\mathrm{~m}, 2 \mathrm{H}, \mathrm{H}_{3}\right.$ and $\left.\mathrm{H}_{5}\right), 3.86(\mathrm{~s}, 3 \mathrm{H}$, $\mathrm{OC}_{\mathrm{H}} 3$ ), 3.77 (s, 3H, COOC$\left.\underline{\mathrm{H}}_{3}\right), 2.32$ and $2.30\left(2 \mathrm{~s}, 6 \mathrm{H}, 2 \mathrm{xOCOC}_{3}\right), 2.37-2.04\left(\mathrm{~m}, 5 \mathrm{H}, \mathrm{H}_{2}, \mathrm{H}_{6}\right.$ and $\left.\mathrm{H}_{4}\right), 1.89$ (ddd, $1 \mathrm{H},{ }^{2} J 13.6 \mathrm{~Hz}$, $\left.{ }^{3} \mathrm{~J} 10.3 \mathrm{~Hz},{ }^{3} \mathrm{~J} 3.4 \mathrm{~Hz}, \mathrm{H}_{4}\right) ;{ }^{13} \mathrm{C}$ NMR $\left(100 \mathrm{MHz}, 295 \mathrm{~K}, \mathrm{CDCl}_{3}\right) \delta 175.1\left(\mathrm{COOCH}_{3}\right), 169.3$ and $168.9\left(2 \mathrm{xOCOCH}_{3}\right), 166.2$ and 165.9 $(2 \mathrm{xCH}=\mathrm{CHCO}), 152.2$ and $151.5\left(\mathrm{C}_{\mathrm{q}} \mathrm{Ar}\right), 144.5$ and $144,3(\underline{\mathrm{CH}}=\mathrm{CHCO}), 141.6,133.3$ and $132.2\left(\mathrm{C}_{\mathrm{q} \mathrm{Ar}}\right), 129.7,129.5,123.4,122.4$, 122.2 and $121.4\left(\mathrm{CH}_{\mathrm{Ar}}\right), 118.4$ and $118.3(\mathrm{CH}=\underline{\mathrm{CHCO}}), 111.3\left(\mathrm{CH}_{\mathrm{Ar}}\right), 74.8\left(\mathrm{COOCH}_{3}\right), 68.9$ and $66.9\left(\mathrm{C}_{3}, \mathrm{C}_{5}\right), 56.0\left(\mathrm{OC} \mathrm{H}_{3}\right), 53.2$ $\left(\mathrm{COOCH}_{3}\right), 39.9$ and $36.8\left(\mathrm{C}_{2}, \mathrm{C}_{6}\right), 35.1\left(\mathrm{C}_{4}\right), 21.3$ and $20.8\left(2 \mathrm{xOCOCH}{ }_{3}\right) ; \mathrm{HRMS}(\mathrm{ESI})$ : calcd for $\mathrm{C}_{31} \mathrm{H}_{32} \mathrm{NaO}_{12}\left[\mathrm{M}^{2} \mathrm{Na}^{+}\right]$: 619.1786, found: 619.1777 .

$10\left(\right.$ EtOAc/ Pentane $=1 / 2$ to $1 / 1$, white solid, 75\%), mp $87-89^{\circ} \mathrm{C},[\alpha]_{\mathrm{D}}^{25}-79.7\left(\right.$ c $\left.1.04, \mathrm{CH}_{2} \mathrm{Cl}_{2}\right)$; IR(ATR) 1762, 1736, 1705, 1636, 1601, $1506 \mathrm{~cm}^{-1}$; ${ }^{1} \mathrm{H}$ NMR $\left(400 \mathrm{MHz}, 295 \mathrm{~K}, \mathrm{CDCl}_{3}\right) \delta 7.64$ and $7.62\left(2 \mathrm{~d}, 2 \mathrm{H},{ }^{3} \mathrm{~J} 16.0 \mathrm{~Hz}, \mathrm{CH}=\mathrm{CHCO}\right), 7.52\left(\mathrm{~d}, 2 \mathrm{H}, J_{\text {ortho }} 8.3\right.$ $\left.\mathrm{Hz}, \mathrm{H}_{\mathrm{Ar}}\right), 7.10\left(\mathrm{~m}, 4 \mathrm{H}, \mathrm{H}_{\mathrm{Ar}}\right), 7.03\left(\mathrm{~d}, 1 \mathrm{H}, J_{\text {ortho }} 8.3 \mathrm{~Hz}, \mathrm{H}_{\mathrm{Ar}}\right), 6.41$ and $6.33\left(2 \mathrm{~d},{ }^{2} \mathrm{H},{ }^{3} \mathrm{~J} 16.0 \mathrm{~Hz}, \mathrm{CH}=\mathrm{CHCO}\right), 5.58-5.47(\mathrm{~m}, 2 \mathrm{H}, \mathrm{H}$ and $\left.\mathrm{H}_{5}\right), 3.85\left(\mathrm{~s}, 3 \mathrm{H}, \mathrm{OCH}_{3}\right), 3.76\left(\mathrm{~s}, 3 \mathrm{H}, \mathrm{COOC}_{3}\right), 2.30$ and $2.29\left(2 \mathrm{~s}, 6 \mathrm{H}, 2 \mathrm{xOCOCH}_{3}\right), 2.37-2.03\left(\mathrm{~m}, 5 \mathrm{H}, \mathrm{H}_{2}, \mathrm{H}_{6}\right.$ and $\left.\mathrm{H}_{4}\right), 1.87$ (ddd, $\left.1 \mathrm{H},{ }^{2} \mathrm{~J} 13.6 \mathrm{~Hz},{ }^{3} \mathrm{~J} 10.3 \mathrm{~Hz},{ }^{3} \mathrm{~J} 3.4 \mathrm{~Hz}, \mathrm{H}_{4}\right) ;{ }^{13} \mathrm{C} \mathrm{NMR}\left(100 \mathrm{MHz}, 295 \mathrm{~K}, \mathrm{CDCl}_{3}\right) \delta 175.0\left(\mathrm{COOCH}_{3}\right), 169.2$ and 168.8 
$\left(2 \mathrm{xO} \underline{C O C H}_{3}\right), 166.1$ and $165.9(2 \mathrm{xCH}=\mathrm{CHCO}), 152.2$ and $151.4\left(\mathrm{C}_{\mathrm{q} A r}\right), 144.6$ and $144.0(2 \mathrm{x} \underline{\mathrm{CH}}=\mathrm{CHCO}), 141.5,133.3$ and $132.0\left(\mathrm{C}_{\mathrm{q}}\right.$ $\mathrm{Ar}), 129.3(2), 123.2,122.2(2)$ and $121.6\left(\mathrm{CH}_{\mathrm{Ar}}\right), 118.3$ and $118.1(\mathrm{CH}=\underline{\mathrm{CHCO}}), 111.1\left(\mathrm{CH}_{\mathrm{Ar}}\right), 74.8\left(\mathrm{C}_{1}\right), 68.9$ and $66.8\left(\mathrm{C}_{3}, \mathrm{C}_{5}\right), 56.0$ $\left(\mathrm{O}_{\underline{C}}{ }_{3}\right), 53.1\left(\mathrm{COOCH}_{3}\right), 39.8$ and $36.8\left(\mathrm{C}_{2}, \mathrm{C}_{6}\right), 35.1\left(\mathrm{C}_{4}\right), 21.2$ and $20.7\left(2 \mathrm{xOCO} \mathrm{H}_{3}\right)$; HRMS $(\mathrm{ESI})$ : calcd for $\mathrm{C}_{31} \mathrm{H}_{33} \mathrm{O}_{12}\left[\mathrm{M}+\mathrm{H}^{+}\right]$: 597.1967, found: 597.1944 .

$11\left(\right.$ EtOAc/ Pentane $=1 / 1$ to 2/1, white solid, 62\%), mp $87-89{ }^{\circ} \mathrm{C},[\alpha]_{\mathrm{D}}^{25}-67.5\left(c 1.05, \mathrm{CH}_{2} \mathrm{Cl}_{2}\right)$; IR(ATR) 1767, 1734, 1709, 1638, $1504 \mathrm{~cm}^{-1}$; ${ }^{1} \mathrm{H}$ NMR (400 MHz, 295K, $\left.\mathrm{CDCl}_{3}\right)$ with $\mathrm{CH}_{2} \mathrm{Cl}_{2} \delta 7.70$ and $7.61\left(2 \mathrm{~d}, 2 \mathrm{H},{ }^{3} \mathrm{~J} 16.0 \mathrm{~Hz}, \mathrm{CH}=\mathrm{CHCO}\right), 7.57,7.40,7.26$ $\left(3 \mathrm{~m}, 6 \mathrm{H}, \mathrm{H}_{\mathrm{Ar}}\right), 7.14\left(\mathrm{~d}, 1 \mathrm{H}, J_{\text {ortho }} 8.4 \mathrm{~Hz}, \mathrm{H}_{\mathrm{Ar}}\right), 6.44$ and $6.35\left(\mathrm{~d}, 1 \mathrm{H},{ }^{3} \mathrm{~J} 16.0 \mathrm{~Hz}, \mathrm{CH}=\mathrm{CHCO}\right), 5.59-5.51\left(\mathrm{~m}, 2 \mathrm{H}, \mathrm{H}_{3}\right.$ and $\left.\mathrm{H}_{5}\right), 3.77(\mathrm{~s}$, $3 \mathrm{H}, \mathrm{COOC}_{\mathrm{H}}$ ), $2.34-2.05\left(\mathrm{~m}, 14 \mathrm{H}, 3 \mathrm{xOCOCH}_{3}, \mathrm{H}_{4}, \mathrm{H}_{6}\right.$ and $\left.\mathrm{H}_{2}\right), 1.90\left(\mathrm{ddd}, 1 \mathrm{H},{ }^{2} \mathrm{~J} 13.6 \mathrm{~Hz},{ }^{3} \mathrm{~J} 10.3 \mathrm{~Hz},{ }^{3} \mathrm{~J} 3.4 \mathrm{~Hz}, \mathrm{H}_{4}\right) ;{ }^{13} \mathrm{C} \mathrm{NMR}$ $\left(100 \mathrm{MHz}, 295 \mathrm{~K}, \mathrm{CDCl}_{3}\right)$ with $\mathrm{CH}_{2} \mathrm{Cl}_{2} \delta 175.1\left(\underline{\mathrm{COOCH}}_{3}\right), 169.2,168.3$ and $168.0\left(3 \times \mathrm{xOCCH}_{3}\right), 166.1$ and $165.6(2 \times \mathrm{CH}=\mathrm{CHCO})$, $152.2\left(\mathrm{C}_{\mathrm{q}} \mathrm{Ar}\right), 144.3(\underline{\mathrm{CH}}=\mathrm{CHCO}), 143.7\left(\mathrm{C}_{\mathrm{q} A r}\right), 143.2(\underline{\mathrm{CH}}=\mathrm{CHCO}), 142.6,133.3$ and $132.2\left(\mathrm{C}_{\mathrm{q}} \mathrm{Ar}\right), 129.4(2), 126.5,124.1,122.9$ and $122.2\left(\mathrm{CH}_{\mathrm{Ar}}\right), 119.3$ and $118.4(2 \mathrm{xCH}=\underline{\mathrm{C} H C O}), 74.8\left(\mathrm{C}_{1}\right), 68.9$ and $67.0\left(\mathrm{C}_{3}, \mathrm{C}_{5}\right), 53.2\left(\mathrm{COOCH}_{3}\right), 39.9$ and $36.8\left(\mathrm{C}_{2}, \mathrm{C}_{6}\right), 35.1\left(\mathrm{C}_{4}\right)$, 21.24, 20.75 and $20.7\left(3 \times \mathrm{XCOCH}_{3}\right)$; HRMS (ESI): calcd for $\mathrm{C}_{32} \mathrm{H}_{32} \mathrm{NaO}_{13}\left[\mathrm{M}+\mathrm{Na}^{+}\right]:$647.1735, found: 647.1707.

$12\left(\right.$ EtOAc/ Pentane $=1 / 2$ to $1 / 1$, white solid, 69\%), mp $87-89^{\circ} \mathrm{C},[\alpha]_{\mathrm{D}}^{25}-75.0\left(c 1.04, \mathrm{CH}_{2} \mathrm{Cl}_{2}\right)$; IR(ATR) 1767, 1738, 1707, 1638, $1504 \mathrm{~cm}^{-1} ;{ }^{1} \mathrm{H}$ NMR $\left(400 \mathrm{MHz}, 295 \mathrm{~K}, \mathrm{CDCl}_{3}\right) \delta 7.63$ and $7.62\left(2 \mathrm{~d}, 2 \mathrm{H},{ }^{3} \mathrm{~J} 16.0 \mathrm{~Hz}, \mathrm{CH}=\mathrm{CHCO}\right), 7.52\left(\mathrm{~d}, 2 \mathrm{H}, J_{\text {ortho }} 8.4 \mathrm{~Hz}, \mathrm{HAr}\right), 7.41-$ $7.36\left(\mathrm{~m}, 2 \mathrm{H}, \mathrm{H}_{\mathrm{Ar}}\right), 7.20$ and $7.10\left(2 \mathrm{~d}, 1 \mathrm{H}+2 \mathrm{H}, J_{\text {ortho }}=8.4 \mathrm{~Hz}, \mathrm{H}_{\mathrm{Ar}}\right), 6.40$ and $6.33\left(2 \mathrm{~d}, 2 \mathrm{H},{ }^{3} \mathrm{~J} 16.0 \mathrm{~Hz}, \mathrm{CH}=\mathrm{CHCO}\right), 5.56-5.45(\mathrm{~m}$, $2 \mathrm{H}, \mathrm{H}_{3}$ and $\left.\mathrm{H}_{5}\right), 3.75\left(\mathrm{~s}, 3 \mathrm{H}, \mathrm{COOC}_{3}\right), 3.24(\mathrm{~m}, 1 \mathrm{H}, \mathrm{OH}-1), 2.29,2.29$, and $2.27\left(3 \mathrm{~s}, 9 \mathrm{H}, 3 \mathrm{xOCOCH}_{3}\right), 2.27-2.05\left(\mathrm{~m}, 5 \mathrm{H}_{1} \mathrm{H}_{4}, \mathrm{H}_{6}\right.$ and $\left.\mathrm{H}_{2}\right), 1.88$ (ddd, $\left.1 \mathrm{H},{ }^{2} \mathrm{~J} 13.6 \mathrm{~Hz},{ }^{3} \mathrm{~J} 10.3 \mathrm{~Hz},{ }^{3} \mathrm{~J} 3.4 \mathrm{~Hz}, \mathrm{H}_{4 \mathrm{a}}\right) ;{ }^{13} \mathrm{C} \mathrm{NMR}\left(100 \mathrm{MHz}, 295 \mathrm{~K}, \mathrm{CDCl}_{3}\right) \delta 175.0\left(\underline{\mathrm{COOCH}}_{3}\right), 169.2,168.1$ and $168.0\left(3 \mathrm{xO} \underline{C O C H}_{3}\right), 165.9(2 \mathrm{xCH}=\mathrm{CHCO}), 152.2\left(\mathrm{C}_{\mathrm{q}} \mathrm{Ar}\right), 144.0(\underline{\mathrm{C} H}=\mathrm{CHCO}), 143.6\left(\mathrm{C}_{\mathrm{q}} \mathrm{Ar}\right), 143.4(\underline{\mathrm{CH}}=\mathrm{CHCO}), 142.4,133.3$ and $132.0\left(\mathrm{C}_{\mathrm{q}} \mathrm{Ar}\right), 129.3(2), 126.5,124.0,123.0$, and 122.2(2) $\left(\mathrm{CH}_{\mathrm{Ar}}\right), 119.4$ and $118.2(2 \mathrm{xCH}=\mathrm{CHCO}), 74.7\left(\mathrm{C}_{1}\right), 68.9$ and $66.8\left(\mathrm{C}_{3}\right.$, $\left.\mathrm{C}_{5}\right), 53.1\left(\mathrm{COOCH}_{3}\right), 39.8$ and $36.8\left(\mathrm{C}_{2}, \mathrm{C}_{6}\right), 35.0\left(\mathrm{C}_{4}\right), 21.2,20.7$ and $20.6\left(3 \mathrm{xOCOCH}_{3}\right) ; \mathrm{HRMS}(\mathrm{ESI}): \mathrm{calcd}$ for $\mathrm{C}_{32} \mathrm{H}_{32} \mathrm{NaO}_{13}[\mathrm{M}+$ $\left.\mathrm{Na}^{+}\right]$: 647.1735 , found: 647.1704 .

13 (diethyl ether $/$ dichloromethane $=1 / 15$ to $1 / 6$, white solid, 54-62\%), mp $80-82{ }^{\circ} \mathrm{C},[\alpha]_{\mathrm{D}}^{25}-83.5(\mathrm{c} 1.04, \mathrm{CH} 2 \mathrm{Cl} 2)$; IR(ATR) 1767, 1709, 1639, $1506 \mathrm{~cm}-1$; $1 \mathrm{H} \mathrm{NMR}\left(400 \mathrm{MHz}, 296 \mathrm{~K}, \mathrm{CDCl}_{3}\right) \delta 7.64$ and $7.58\left(2 \mathrm{~d}, 2 \mathrm{H},{ }^{3} \mathrm{~J} 16.0 \mathrm{~Hz}, \mathrm{CH}=\mathrm{CHCO}\right), 7.39-7.34(\mathrm{~m}$, $\left.2 \mathrm{H}, \mathrm{H}_{\mathrm{Ar}}\right), 7.19\left(\mathrm{~d}, 1 \mathrm{H}\right.$, Jortho $\left.=8.4 \mathrm{~Hz}, \mathrm{H}_{\mathrm{Ar}}\right), 7.11-7.01\left(\mathrm{~m}, 3 \mathrm{H}, \mathrm{H}_{\mathrm{Ar}}\right), 6.40$ and $6.32\left(\mathrm{~d}, 1 \mathrm{H},{ }^{3} \mathrm{~J} 16.0 \mathrm{~Hz}, \mathrm{CH}=\mathrm{CHCO}\right), 5.56-5.47(\mathrm{~m}$, $2 \mathrm{H}, \mathrm{H}_{3}$ and $\left.\mathrm{H}_{5}\right), 3.85\left(\mathrm{~s}, 3 \mathrm{H}, \mathrm{OCH}_{3}\right), 3.75\left(\mathrm{~s}, 3 \mathrm{H}, \mathrm{COOCH}_{3}\right), 3.30(\mathrm{~s}, 1 \mathrm{H}, \mathrm{OH}), 2.30,2.28$ and $2.27(3 \mathrm{~s}, 9 \mathrm{H}, 3 \mathrm{x} \mathrm{OCOCH}), 2.27-1.92$ $\left(\mathrm{m}, 5 \mathrm{H}, \mathrm{H}_{4}, \mathrm{H}_{2}\right.$ and $\left.\mathrm{H}_{6}\right), 1.86\left(\mathrm{ddd}, 1 \mathrm{H},{ }^{2} \mathrm{~J} 13.6 \mathrm{~Hz},{ }^{3} \mathrm{~J} 10.4,{ }^{3} \mathrm{~J} 3.5 \mathrm{~Hz}, \mathrm{H}_{4}\right) ;{ }^{13} \mathrm{C} \mathrm{NMR}\left(100 \mathrm{MHz}, 297 \mathrm{~K}, \mathrm{CDCl}_{3}\right) \delta 175.0\left(\mathrm{COOCH}_{3}\right)$, 168.8, 168.1 and $168.0\left(3 \mathrm{xOCOCH}_{3}\right), 166.1$ and $165.6(2 \mathrm{xCH}=\mathrm{CHCO}), 151.4(\mathrm{Cq} \mathrm{Ar}), 144.6(\mathrm{CH}=\mathrm{CHCO}), 143.6(\mathrm{Cq} \mathrm{Ar}), 143.2$ $(\mathrm{CH}=\mathrm{CHCO}), 142.5,141.5,133.3$ and $133.1(\mathrm{Cq} \mathrm{Ar}), 126.4,124.0,123.2,122.8$ and $121.5\left(\mathrm{CH}_{\mathrm{Ar}}\right), 119.1$ and $118.4(2 \times C H=\mathrm{CHCO})$, $111.2\left(\mathrm{CH}_{\mathrm{Ar}}\right), 74.7\left(\mathrm{C}_{1}\right), 68.8$ and $66.9\left(\mathrm{C}_{3}, \mathrm{C}_{5}\right), 56.0\left(\mathrm{CH}_{3}\right), 53.1\left(\mathrm{COOCH}_{3}\right), 39.7$ and $36.7\left(\mathrm{C}_{2}, \mathrm{C}_{6}\right), 35.0\left(\mathrm{C}_{4}\right), 20.7\left(3 \times \mathrm{XCOCH}_{3}\right)$; HRMS (ESI): calcd for $\mathrm{C}_{33} \mathrm{H}_{34} \mathrm{NaO}_{14}[\mathrm{M}+\mathrm{Na}+]$ : 677.1841 , found: 677.1830 .

General procedure for the cleavage of methyl ester. LiI (10 equiv.) was added to a solution of the methyl ester (1 equiv.) in EtOAc $(0.14 \mathrm{M})$ then the mixture was heated under reflux for $5 \mathrm{~h}$. After cooling down to room temperature, the mixture was diluted with EtOAc, and $1 \mathrm{M} \mathrm{HCl}$ added. After extraction, the organic layer was dried over $\mathrm{MgSO}_{4}$, concentrated to give the crude residue, usually characterized such as and used directly in the next step.

15 (60 mg, quantitative crude yield, light yellow oil); ${ }^{1} \mathrm{H}$ NMR $\left(400 \mathrm{MHz}, 295 \mathrm{~K}, \mathrm{CD}_{3} \mathrm{OD}\right) \delta 7.70\left(\mathrm{~d}, 2 \mathrm{H},{ }^{3} \mathrm{~J} 16.0 \mathrm{~Hz}, \mathrm{C} \underline{\mathrm{H}}=\mathrm{CHCO}\right)$, 7.63-7.60 and 7.51-7.49 (2m, 5H, ArH + $\underline{\mathrm{H}}=\mathrm{CHCO}), 7.24$ and $7.13\left(2 \mathrm{~d}, 1+2 \mathrm{H}, \mathrm{J} 8 \mathrm{HZ}, \mathrm{H}_{\mathrm{Ar}}\right), 6.52 \mathrm{and} 6.45\left(2 \mathrm{~d}, 2 \mathrm{H},{ }^{3} \mathrm{~J} 16.0 \mathrm{~Hz}\right.$, $\mathrm{CH}=\mathrm{C} \underline{\mathrm{HCO}}), 5.47\left(\mathrm{~m}, 2 \mathrm{H}, \mathrm{H}_{3}\right.$ and $\left.\mathrm{H}_{5}\right), 2.42\left(\mathrm{dd}, 1 \mathrm{H},{ }^{2} \mathrm{~J} 13.7 \mathrm{~Hz},{ }^{3} \mathrm{~J} 3.8 \mathrm{~Hz}, \mathrm{H}_{2}, \mathrm{H}_{4}\right.$ or $\left.\mathrm{H}_{6}\right), 2.36-2.20\left(\mathrm{~m}, 1 \mathrm{H}, \mathrm{H}_{2}, \mathrm{H}_{4}\right.$ or $\left.\mathrm{H}_{6}\right), 2.28,2.27$ $\left(2 \mathrm{~s}, 9 \mathrm{H}, 3 \mathrm{xOCOCH}_{3}\right), 2.11-2.00\left(\mathrm{~m}, 3 \mathrm{H}, \mathrm{H}_{2}, \mathrm{H}_{4}\right.$ and/or $\left.\mathrm{H}_{6}\right), 1.94$ (dd, $1 \mathrm{H},{ }^{2} \mathrm{~J} 13.7 \mathrm{~Hz},{ }^{3} \mathrm{~J} 6.4 \mathrm{~Hz}, \mathrm{H}_{2}, \mathrm{H}_{4}$ or $\left.\mathrm{H}_{6}\right) ;{ }^{13} \mathrm{C} \mathrm{NMR}(100 \mathrm{MHz}$, $\left.295 \mathrm{~K}, \mathrm{CD}_{3} \mathrm{OD}\right) \delta 177.3(\underline{\mathrm{COOH}}), 170.8,169.8$, and $169.6\left(3 \mathrm{xOCOCH}_{3}\right), 167.7$ and $167.2(2 \mathrm{xCH}=\mathrm{CH} \underline{\mathrm{CO}}), 153.7\left(\mathrm{C}_{\mathrm{q}} \mathrm{Ar}\right), 145.2$ $(\underline{\mathrm{CH}}=\mathrm{CHCO}), 145.1\left(\mathrm{C}_{\mathrm{q}} \mathrm{Ar}\right), 144.5(\underline{\mathrm{CH}}=\mathrm{CHCO}), 144.0,134.5$ and $133.4\left(\mathrm{C}_{\mathrm{q} \mathrm{Ar}}\right), 130.4(2), 127.7,125.1,124.1$ and $123.4\left(\mathrm{CH}_{\mathrm{Ar}}\right)$, $120.1(2 \mathrm{xCH}=\underline{\mathrm{CHCO}}), 119.4(2 \mathrm{xCH}=\underline{\mathrm{CHCO}}), 75.0\left(\mathrm{C}_{1}\right), 70.1$ and $69.2\left(\mathrm{C}_{3}, \mathrm{C}_{5}\right), 39.9,38.7,35.9\left(\mathrm{C}_{2}, \mathrm{C}_{4}, \mathrm{C}_{6}\right), 20.9,20.5(2)$ (3xOCOCH${ }_{3}$ ); HRMS (ESI): calcd for $\mathrm{C}_{31} \mathrm{H}_{30} \mathrm{NaO}_{13}\left[\mathrm{M}+\mathrm{Na}^{+}\right]$: 663.1579, found: 663.1581.

16 (63 mg, quantitative crude yield, light yellow oil), $[\alpha]_{\mathrm{D}}^{32}-80.3$ (c 1.15 in MeOH) IR(ATR) $2930,1765,1705,1635,1504 \mathrm{~cm}^{-1}$; ${ }^{1} \mathrm{H}$ NMR $\left(400 \mathrm{MHz}, 295 \mathrm{~K}, \mathrm{CD}_{3} \mathrm{OD}\right) \delta$ 7.68-7.62 (m, 4H, $\left.\mathrm{H}_{\mathrm{Ar}}+2 \mathrm{xC} \underline{\mathrm{H}}=\mathrm{CHCO}\right), 7.49,7.24$ and 7,13 $(3 \mathrm{~m}, 2+1+2 \mathrm{H}, \mathrm{ArH}), 6.52 \mathrm{and}$ $6.45\left(2 \mathrm{~d}, 2 \mathrm{x} 1 \mathrm{H},{ }^{3} \mathrm{~J} 16.0 \mathrm{~Hz}, 2 \mathrm{xCH}=\mathrm{C} \underline{\mathrm{HCO}}\right), 5.47\left(\mathrm{~m}, 2 \mathrm{H}, \mathrm{H}_{3}\right.$ and $\left.\mathrm{H}_{5}\right), 2.42\left(\mathrm{dd}, 1 \mathrm{H},{ }^{2} J 13.7 \mathrm{~Hz},{ }^{3} \mathrm{~J} 3.8 \mathrm{~Hz}, \mathrm{H}_{2}, \mathrm{H}_{4} \mathrm{or} \mathrm{H}_{6}\right), 2.34-2.30$ $\left(\mathrm{m}, 1 \mathrm{H}, \mathrm{H}_{2}, \mathrm{H}_{4}\right.$ or $\left.\mathrm{H}_{6}\right), 2.28,2.27\left(2 \mathrm{~s}, 9 \mathrm{H}, 3 \mathrm{xOCOCH}_{3}\right), 2.12-2.00\left(\mathrm{~m}, 3 \mathrm{H}, \mathrm{H}_{2}, \mathrm{H}_{4}\right.$ and/or $\left.\mathrm{H}_{6}\right), 1.94\left(\mathrm{dd}, 1 \mathrm{H},{ }^{2} \mathrm{~J} 13.7 \mathrm{~Hz},{ }^{3} \mathrm{~J} 6.4 \mathrm{~Hz}\right.$, $\mathrm{H}_{2}, \mathrm{H}_{4}$ or $\left.\mathrm{H}_{6}\right) ;{ }^{13} \mathrm{C}$ NMR $\left(100 \mathrm{MHz}, 295 \mathrm{~K}, \mathrm{CD}_{3} \mathrm{OD}\right) \delta 177.4(\underline{\mathrm{COOH}}), 170.8,169.8$, and $169.7(3 \mathrm{xO} \underline{\mathrm{COCH}}), 167.5\left(2 \times \mathrm{CH}_{3}=\mathrm{CHCO}\right)$, $153.8\left(\mathrm{C}_{\mathrm{q} \mathrm{Ar}}\right), 145.3(\underline{\mathrm{CH}}=\mathrm{CHCO}), 145.1\left(\mathrm{C}_{\mathrm{q} \mathrm{Ar}}\right), 144.4(\underline{\mathrm{CH}}=\mathrm{CHCO}), 144.0\left(\mathrm{C}_{\mathrm{q} \mathrm{Ar}}\right), 134.6$ and $133.4\left(\mathrm{C}_{\mathrm{q}} \mathrm{Ar}\right), 130.5(2), 127.6,125.1$, 124.1 and 123.3(2) $\left(\mathrm{CH}_{\mathrm{Ar}}\right), 120.5$ and $119.1(2 \mathrm{xCH}=\underline{\mathrm{C}} \mathrm{HCO}), 75.1\left(\mathrm{C}_{1}\right), 70.3$ and $69.0\left(\mathrm{C}_{3}, \mathrm{C}_{5}\right), 40.0,38.6,35.9\left(\mathrm{C}_{2}, \mathrm{C}_{4}, \mathrm{C}_{6}\right), 20.9$, 20.5 (2) $\left(3 \mathrm{xOCOCH}_{3}\right)$; HRMS (ESI): calcd for $\mathrm{C}_{31} \mathrm{H}_{30} \mathrm{NaO}_{13}\left[\mathrm{M}+\mathrm{Na}^{+}\right]$: 633.1579, found: 663.1554. 
17 (180 mg, 91\% crude yield, light yellow oil), [ $\alpha]_{\mathrm{D}}^{26}-106.8$ (c 0.99 in MeOH); IR(ATR) 3356, 3337, 2941, 2833, 1765, 1707, 1636, 1601, $1508 \mathrm{~cm}^{-1}$; ${ }^{1} \mathrm{H}$ NMR $\left(400 \mathrm{MHz}, 298 \mathrm{~K}, \mathrm{CD}_{3} \mathrm{OD}\right) \delta 7.66$ and $7.59\left(2 \mathrm{~d}, 2 \mathrm{H},{ }^{3} \mathrm{~J} 16.0 \mathrm{~Hz}, 2 \mathrm{xCH}=\mathrm{CHCO}\right), 7.49-7.43,7.29-$ 7.12 and $7.03\left(3 \mathrm{~m}, 2 \mathrm{H}+3 \mathrm{H}+1 \mathrm{H}, \mathrm{H}_{\mathrm{Ar}}\right), 6.52$ and $6.43\left(2 \mathrm{~d}, 2 \mathrm{H},{ }^{3} \mathrm{~J} 16.0 \mathrm{~Hz}, 2 \mathrm{xCH}=\mathrm{C} \underline{\mathrm{HCO}}\right), 5.47\left(\mathrm{~m}, 2 \mathrm{H}, \mathrm{H}_{3}\right.$ and $\left.\mathrm{H}_{5}\right), 3.80(\mathrm{~s}, 3 \mathrm{H}$, $\left.\mathrm{OCH}_{3}\right), 2.41\left(\mathrm{dd}, 1 \mathrm{H},{ }^{2} \mathrm{~J} 13.7 \mathrm{~Hz},{ }^{3} \mathrm{~J} 3.8 \mathrm{~Hz}, \mathrm{H}_{2}, \mathrm{H}_{4}\right.$ or $\left.\mathrm{H}_{6}\right), 2.36-2.20\left(\mathrm{~m}, 1 \mathrm{H}, \mathrm{H}_{2}, \mathrm{H}_{4}\right.$ or $\left.\mathrm{H}_{6}\right), 2.27,2.26$, and $2.25(3 \mathrm{~s}, 9 \mathrm{H}$, $\left.3 \mathrm{xOCOCH}_{3}\right), 2.05\left(\mathrm{~m}, 3 \mathrm{H}, \mathrm{H}_{2}, \mathrm{H}_{4}\right.$ and/or $\left.\mathrm{H}_{6}\right), 1.94$ (dd, $1 \mathrm{H},{ }^{2} \mathrm{~J} 13.7 \mathrm{~Hz},{ }^{3} \mathrm{~J} 6.4 \mathrm{~Hz}, \mathrm{H}_{2}, \mathrm{H}_{4}$ or $\left.\mathrm{H}_{6}\right) ;{ }^{13} \mathrm{C} \mathrm{NMR}\left(100 \mathrm{MHz}, 295 \mathrm{~K}, \mathrm{CD}{ }_{3} \mathrm{OD}\right)$ $\delta 177.3\left(\underline{\mathrm{COOCH}_{3}}\right), 170.4,169.8$, and $169.7\left(\mathrm{O}_{\underline{C O C H}}\right), 167.7(\underline{\mathrm{CH}}=\mathrm{CHCO}), 167.2(\underline{\mathrm{C}} \mathrm{H}=\mathrm{CHCO}), 152.8(\mathrm{C} \mathrm{q} \mathrm{Ar}), 145.6(\underline{\mathrm{CH}}=\mathrm{CHCO})$, $145.1\left(\mathrm{C}_{\mathrm{q} A r}\right), 144.4(\underline{\mathrm{CH}}=\mathrm{CHCO}), 143.9\left(\mathrm{C}_{\mathrm{q} \mathrm{Ar}}\right), 142.8\left(\mathrm{C}_{\mathrm{q} \mathrm{Ar}}\right), 134.7\left(\mathrm{C}_{\mathrm{q} \mathrm{Ar}}\right), 134.5\left(\mathrm{C}_{\mathrm{q}} \mathrm{Ar}\right), 127.7\left(\mathrm{CH}_{\mathrm{Ar}}\right), 125.1\left(\mathrm{CH}_{\mathrm{Ar}}\right), 124.2\left(\mathrm{CH}_{\mathrm{Ar}}\right)$, $124.1\left(\mathrm{CH}_{\mathrm{Ar}}\right), 122.4\left(\mathrm{CH}_{\mathrm{Ar}}\right), 120.1(\mathrm{CH}=\underline{\mathrm{CHCO}}), 119.5(\mathrm{CH}=\underline{\mathrm{CHCO}}), 112.6\left(\mathrm{CH}_{\mathrm{Ar}}\right), 75.0\left(\mathrm{C}_{1}\right), 70.1\left(\mathrm{C}_{3}\right.$ or $\left.\mathrm{C}_{5}\right), 69.1\left(\mathrm{C}_{3}\right.$ or $\left.\mathrm{C}_{5}\right), 56.5$ $\left(\mathrm{PhOCH}_{3}\right), 39.9\left(\mathrm{C}_{2}\right.$ or $\mathrm{C}_{4}$ or $\left.\mathrm{C}_{6}\right), 38.7\left(\mathrm{C}_{2}\right.$ or $\mathrm{C}_{4}$ or $\left.\mathrm{C}_{6}\right), 35.89\left(\mathrm{C}_{2}\right.$ or $\mathrm{C}_{4}$ or $\left.\mathrm{C}_{6}\right), 20.8,20.7$, and $20.50\left(\mathrm{OCOCH}_{3}\right)$; HRMS (ESI): calcd for $\mathrm{C}_{32} \mathrm{H}_{32} \mathrm{NaO}_{14}\left[\mathrm{M}+\mathrm{Na}^{+}\right]$: 663.1684, found: 663.1678 .

General procedure for the deprotection of aromatic acetates. To a solution of the acetylated compound 14, 15 or 16 in acetone $(1.5 \mathrm{~mL}$ for $100 \mathrm{mg})$ was added a $3 \mathrm{M} \mathrm{HCl}$ aqueous solution $(0.5 \mathrm{~mL})$ and the mixture was refluxed for $4 \mathrm{~h}$ till completion. After cooling down to room temperature, the mixture was diluted with EtOAc and washed with a saturated $\mathrm{NaCl}$ aqueous solution. The organic layer was dried then concentrated to give the deprotected heterodiester of 4-deoxy quinic acid 18, 19 or 20. A rapid purification by semi-preparative HPLC was run before insecticidal assays.

18 (light yellow oil, quantitative crude yield), $[\alpha]_{\mathrm{D}}^{32}-70.2$ (c 1.16 in MeOH), IR(ATR) 3308, 2945, 2833, 1690, 1632, 1605,1514 $\mathrm{cm}^{-1}$; ${ }^{1} \mathrm{H}$ NMR $\left(400 \mathrm{MHz}, 295 \mathrm{~K}, \mathrm{CD}_{3} \mathrm{OD}\right) \delta 7.66$ and $7.54\left(2 \mathrm{~d}, 2 \mathrm{x} 1 \mathrm{H},{ }^{3} \mathrm{~J} 16.0 \mathrm{~Hz}, 2 \mathrm{xC} \underline{\mathrm{H}}=\mathrm{CHCO}\right), 7.47-6.78\left(\mathrm{~m}, 7 \mathrm{H}, \mathrm{H}_{\mathrm{Ar}}\right), 6.35 \mathrm{and}$ $6.23\left(2 \mathrm{~d}, 2 \mathrm{x} 1 \mathrm{H},{ }^{3} \mathrm{~J} 16.0 \mathrm{~Hz}, 2 \mathrm{xCH}=\mathrm{C} \underline{\mathrm{HCO}}\right), 5.45\left(\mathrm{~m}, 2 \mathrm{H}, \mathrm{H}_{3}\right.$ and $\left.\mathrm{H}_{5}\right), 2.43-2.29$ and $2.11-1.90\left(2 \mathrm{~m}, 2 \mathrm{H}+4 \mathrm{H}, \mathrm{H}_{2}, \mathrm{H}_{4}\right.$ and $\left.\mathrm{H}_{6}\right) ;{ }^{13} \mathrm{C} \mathrm{NMR}$ $\left(100 \mathrm{MHz}, 295 \mathrm{~K}, \mathrm{CD}_{3} \mathrm{OD}\right) \delta 177.5(\underline{\mathrm{COOH}}), 168.6(\mathrm{CH}=\mathrm{CHCO}), 168.3(\mathrm{CH}=\mathrm{CHCO}), 161.2(2)$ and $149.5\left(\mathrm{C}_{\mathrm{q}} \mathrm{Ar}\right), 147.1$ and 146.7 $(\underline{\mathrm{CH}}=\mathrm{CHCO}), 131.2\left(2 \times \mathrm{CH}_{\mathrm{Ar}}\right), 127.8$ and $127.2\left(\mathrm{C}_{\mathrm{q} \mathrm{Ar}}\right), 123.1116 .8(2)$ and $116.5\left(\mathrm{CH}_{\mathrm{Ar}}\right), 115.5(\mathrm{CH}=\underline{\mathrm{CHCO}}), 115.2(\mathrm{CH}=\underline{\mathrm{CHCO}})$, $75.1\left(\mathrm{C}_{1}\right), 70.0$ and $68.7\left(\mathrm{C}_{3}, \mathrm{C}_{5}\right), 40.0,38.7$ and $36.0\left(\mathrm{C}_{2}, \mathrm{C}_{4}, \mathrm{C}_{6}\right)$; HRMS (ESI): calcd for $\mathrm{C}_{25} \mathrm{H}_{24} \mathrm{NaO}_{10}\left[\mathrm{M}+\mathrm{Na}^{+}\right]: 507.1262$, found: 507.1250 .

19 (light yellow oil, quantitative crude yield), $[\alpha]_{\mathrm{D}}^{32}-61.4\left(c 0.96\right.$ in $\left.\mathrm{CH}_{3} \mathrm{OH}\right), \mathrm{IR}(\mathrm{ATR}) 3320,2359,1688,1603,1514 \mathrm{~cm}^{-1} ;{ }^{1} \mathrm{H}$ NMR (400 MHz, 298K, CD 3 OD) $\delta 7.60$ and $7.58\left(2 \mathrm{~d}, 2 \mathrm{H},{ }^{3} J 15.9 \mathrm{~Hz}, 2 \mathrm{xCH}=\mathrm{CHCO}\right), 7.46\left(\mathrm{~m}, 2 \mathrm{H}, \mathrm{H}_{\mathrm{Ar}}\right), 7.07-6.78\left(\mathrm{~m}, 5 \mathrm{H}, \mathrm{H}_{\mathrm{Ar}}\right)$, 6.29 and $6.28\left(2 \mathrm{~d}, 2 \mathrm{H},{ }^{3} \mathrm{~J} 15.9 \mathrm{~Hz}, 2 \mathrm{xCH}=\mathrm{C} \underline{\mathrm{HCO}}\right), 5.45\left(\mathrm{~m}, 2 \mathrm{H}, \mathrm{H}_{3}\right.$ and $\left.\mathrm{H}_{5}\right), 2.40-2.30$ and $2.06-1.89\left(2 \mathrm{~m}, 2 \mathrm{H}+4 \mathrm{H}, \mathrm{H}_{2}, \mathrm{H}_{4}, \mathrm{H}_{6}\right) ;{ }^{3} \mathrm{C}$ NMR $\left(100 \mathrm{MHz}, 298 \mathrm{~K}, \mathrm{CD}_{3} \mathrm{OD}\right) \delta 177.6(\underline{\mathrm{COOH}}), 168.6$ and $168.3(\mathrm{CH}=\mathrm{CHCO}), 161.3(2)$ and $149.5\left(\mathrm{C}_{\mathrm{q}} \mathrm{Ar}\right), 147.0$ and 146.7 $(2 \mathrm{x} \underline{\mathrm{CH}}=\mathrm{CHCO}), 131.2$ and $131.0\left(2 \mathrm{xCH}_{\mathrm{Ar}}\right), 127.8$ and $127.2\left(\mathrm{C}_{\mathrm{q} \mathrm{Ar}}\right), 123.0,116.8(2), 116.5$ and $115.5\left(\mathrm{CH}_{\mathrm{Ar}}\right), 115.2$ and 115.1 $(2 \mathrm{xCH}=\underline{\mathrm{CHCO}}), 75.1\left(\mathrm{C}_{1}\right), 70.0$ and $68.8\left(\mathrm{C}_{3}, \mathrm{C}_{5}\right), 40.1,38.8$ and $36.0\left(\mathrm{C}_{2}, \mathrm{C}_{4}, \mathrm{C}_{6}\right)$; HRMS (ESI): calcd for $\mathrm{C}_{25} \mathrm{H}_{24} \mathrm{NaO}_{10}\left[\mathrm{M}+\mathrm{Na}^{+}\right]$: 507.1262, found: 507.1252 .

20 (light yellow oil, quantitative crude yield), $[\alpha]_{\mathrm{D}}^{25}-77.6$ (c 0.98 in $\left.\mathrm{MeOH}\right)$, IR(ATR) 3393, 2950, 2360, 1680, 1654, 1629,1603 $\mathrm{cm}^{-1} ;{ }_{1}^{1} \mathrm{H}$ NMR (400 MHz, 298K, CD $\left.3 \mathrm{OD}\right) \delta 7.64$ and $7.53\left(2 \mathrm{~d}, 2 \mathrm{H},{ }^{3} \mathrm{~J} 15.9 \mathrm{~Hz}, 2 \mathrm{xC} \underline{\mathrm{H}}=\mathrm{CHCO}\right), 7.19-6.78\left(\mathrm{~m}, 7 \mathrm{H}, \mathrm{H}_{\mathrm{Ar}}\right), 6.38$ and 6.22 $\left(2 \mathrm{~d}, 2 \mathrm{H},{ }^{3} \mathrm{~J} 15.9 \mathrm{~Hz}, 2 \mathrm{xCH}=\mathrm{C} \underline{\mathrm{HCO}}\right), 5.45\left(\mathrm{~m}, 2 \mathrm{H}, \mathrm{H}_{3}\right.$ and $\left.\mathrm{H}_{5}\right), 3.89\left(\mathrm{~s}, 3 \mathrm{H}, \mathrm{OC}_{3}\right), 2.42-2.27$ and $2.11-1.91\left(2 \mathrm{~m}, 2 \mathrm{H}+4 \mathrm{H}, \mathrm{H}_{2}, \mathrm{H}_{4}, \mathrm{H}_{6}\right)$; ${ }^{13} \mathrm{C}$ NMR $\left(100 \mathrm{MHz}, 298 \mathrm{~K}, \mathrm{CD}_{3} \mathrm{OD}\right) \delta 177.4(\underline{\mathrm{COOH}}), 168.5$ and $168.3(2 \mathrm{xCH}=\mathrm{CHCO}), 150.4,149.5,149.3\left(\mathrm{C}_{\mathrm{q}} \mathrm{Ar}\right), 147.1$ and 146.9 $(2 \mathrm{x} \underline{\mathrm{CH}}=\mathrm{CHCO}), 146.7,127.8,127.7\left(\mathrm{C}_{\mathrm{q} \mathrm{Ar}}\right), 124.1,123.1,116.5$ and $116.4\left(\mathrm{CH}_{\mathrm{Ar}}\right), 115.9$ and $115.20(\mathrm{CH}=\underline{\mathrm{CHCO}}), 115.18$ and 111.6 $\left(\mathrm{CH}_{\mathrm{Ar}}\right), 75.1\left(\mathrm{C}_{1}\right), 70.0$ and $\left.68.7\left(\mathrm{C}_{3}, \mathrm{C}_{5}\right), 56.4\left(\mathrm{O}_{\underline{C}}\right)_{3}\right), 40.0,38.7$ and $36.0\left(\mathrm{C}_{2}, \mathrm{C}_{4}, \mathrm{C}_{6}\right)$; HRMS $(\mathrm{ESI})$ : calcd for $\mathrm{C}_{26} \mathrm{H}_{26} \mathrm{NaO}_{11}[\mathrm{M}+$ $\mathrm{Na}^{+}$]: 537.1367, found: 537.1366 .

\section{UPLC-MS QTOF Investigation / Mass spectrometry analysis}

A UPLC apparatus (U3000, Thermo Fisher Scientific) was used, coupled with a high-resolution hybrid QTOF (Impact II, Bruker) mass spectrometer. For the chromatographic resolution, a biphenyl column (Restek ${ }^{\circledR}, 5 \mathrm{~cm} * 3 \mathrm{~mm} ; 2.7 \mu \mathrm{m}$ ) with a mobile phase of (A) ultra-pure water (Milli-Q grade) $+0.1 \%$ formic acid and (B) Acetonitrile/Methanol (40/60) (optima MS grade, Thermo Fisher Scientific) $+0.1 \%$ formic acid as a mobile phase, at a flow of $800 \mu \mathrm{L} / \mathrm{min}$ for a $200 \mathrm{~nL}$ volume of injection. Mass Spectrometry detection was performed using negative mode electrospray ionisation (source temperature : $200^{\circ} \mathrm{C}$; Capillary voltage $3000 \mathrm{~V}$, nebulisation gas pressure : 45 Psi ; Mass range $50-1000 \mathrm{Da}$ ); UV detection at 250 and $380 \mathrm{~nm}$.

\section{Mortality data and growth inhibition assay}

The natural compound 1 (3,5-dicaffeoyl quinic acid), was extracted with ethanol/water (70/30) from lyophilized non-tuberized roots of sweet potato Ipomea batatas and purified by semi-preparative HPLC on a Hibar® $250 \mathrm{~mm}$ x $25 \mathrm{~mm}$ column filled with Lichrospher ${ }^{\circledR} 100$ RP18e $5 \mu \mathrm{M}$ stationary phase. The compound was eluted with an acidified water/methanol gradient. ${ }^{22}$ Compounds were administrated pure by weighing after HPLC purification, solubilized at $1 \mathrm{mM}$ in a standard AP3 artificial diet for the pea aphid Acyrthosiphon pisum, ${ }^{38}$ and diluted 3 times to obtain the experimental dose range $(125 \mu \mathrm{M}-1 \mathrm{mM})$. Toxicity was evaluated by scoring 
survival daily over the whole nymphal life of the pea aphid (7 days), starting from neonate aphids born on faba bean leaves. Growth was also measured by weighing adult aphids on an analytical microbalance (Mettler AE163) at the closest $10 \mu \mathrm{g}$, as fully described previously for testing peptide toxicity. ${ }^{39}$ Aphid weights were analysed by ANOVA followed by Tukey-Kramer HSD test for comparing multiple means (treating separately either the dose factor for every compound, or the compound factor, at each dose; see Table 1). All analyses were made with JMP software, v11 (SAS Institute Cary USA, MacOS version).

Four separate experiments were needed to test all eight compounds, 3a-3c and 16, 17, 18, 19, 20 and the original 1 compound was used/repeated in each test.

\section{Conclusions}

New heterodiesters of 4-deoxy quinic acid were prepared through various combinations of two sequential monoesterifications with acetylated feruloyl, $p$-coumaroyl or caffeoyl chloride. Five di-(hydroxycinnamoyl)-4-deoxy quinic acids, featuring either acetylated or free phenol groups could thus be added to three previously described acetylated homodiesters for a novel insecticidal assay to investigate the influence of these structural modifications on aphicidal activity. Much effort was put into the structural elucidation of different isolated intermediates to ascertain the biological response of structural isomers. An interesting difference was observed for two regioisomeric deacetylated 3,5-caffeoylcoumaroyl-4-deoxy quinic acids albeit a lower toxicity than natural 3, 5dicaffeoylquinic acid. Both mortality data and growth inhibition were analysed and four compounds were found to exhibit higher aphicidal activities than the reference compound. The acetylation of phenol groups proved to be advantageous to the activity of homodiesters while the presence of at least one caffeoyl moiety on quinic nucleus seems required for significant toxicity.

\section{Conflicts of interest}

There are no conflict to declare.

\section{Acknowledgements}

We gratefully acknowledge INSA-Lyon for financial support (BQR 2011) and the China Scholarship Council for a PhD grant to X.L. We would also like to thank Marie-Noëlle Corre for her help in preparing 3,5-dicaffeoylquinic acid and Alexandra BerliozBarbier (CCSM) for UPLC-HRMS analysis.

Electronic Supplementary Information (ESI) available: [Table S1 Preparation of monoesters 5a/5b, 6a/6b, 7a/7b; Table S2 Second esterification towards heterodiesters; ${ }^{1} \mathrm{H}$ NMR spectra for couples of monoesters $\mathbf{5 a} / \mathbf{5 b}, \mathbf{6 a} / \mathbf{6 b}, \mathbf{7 a} / \mathbf{7} \mathbf{b} ;{ }^{1} \mathrm{H}$ and ${ }^{13} \mathrm{C}$ NMR spectra for compounds 5a, 5b, 6a, 6b, 7a, 7b, 9-14, 15-20; UPLC-MS QTOF Investigation / Mass spectrometry analysis; Table S3 Survival analysis (LT50 = Lethal time for $50 \%$ death of population)].

\section{Notes and references}

1 Petroski, R. J.; Stanley, D. W., J. Agr. Food Chem. 2009, 57, 8171-8179.

2 Rousselin, A.; Bevacqua, D.; Sauge, M.-H.; Lescourret, F.; Mody, K.; Jordan, M.-O., Agron. Sustain. Dev. 2017, 37,1 1-13.

3 Song, H. P.; Chen, J.; Hong, J. Y.; Hao, H.; Qi, L. W.; Lu, J.; Fu, Y.; Wu, B.; Yang, H.; Li, P., Chem. Commun. 2015, 51, 14941497.

4 Mirón-Mérida, V. A.; Yáñez-Fernández, J.; Montañez-Barragán, B.; Barragán Huerta, B. E., LWT-Food Sci. Technol. 2019, 101, 167-174.

5 Sinisi, V.; Stevaert, A.; Berti, F.; Forzato, C.; Benedetti, F.; Navarini, L.; Camps, A.; Persoons, L.; Vermeire, K., Planta Med. 2017, $83,615-623$.

6 Domitrovic, R.; Cvijanovic, O.; Susnic, V.; Katalinic, N., Toxicol. 2014, 324, 98-107.

7 Miyamae, Y.; Kurisu, M.; Murakami, K.; Han, J.; Isoda, H.; Irie, K.; Shigemori, H., Bioorg. Med. Chem. 2012, 20, 5844-5849.

8 Deng, J.; Qi, X.-L.; Guan, Z.-Z.; Yan, X.-M.; Huang, Y.; Wang, Y.-L., J. Pharm. Pharmacol. 2013, 65, 1736-1744. 
9 Hemmerle, H.; Burger, H. J.; Below, P.; Schubert, G.; Rippel, R.; Schindler, P. W.; Paulus, E.; Herling, A. W., J. Med. Chem. 1997, 40, 137-145.

10 Xu, D.; Wang, Q.; Zhang, W.; Hu, B.; Zhou, L.; Zeng, X.; Sun, Y., J. Agr. Food Chem. 2015, 63, 3694-3703.

11 Xie, M.; Chen, G.; Wan, P.; Dai, Z.; Zeng, X.; Sun, Y., J. Agr. Food Chem. 2019, 67, 171-183.

12 Smith, C. M.; Chuang, W. P., Pest Manag. Sci. 2014, 70, 528-540.

13 Harrison, H. F., Jr.; Mitchell, T. R.; Peterson, J. K.; Wechter, W. P.; Majetich, G. F.; Snook, M. E., J. Am. Soc. Horticultural. Sci. 2008, 133, 492-500.

14 Cole, R. A., Ann. Appl. Biol. 1985, 106, 211-217.

15 Mhlongo, M. I.; Piater, L. A.; Steenkamp, P. A.; Madala, N. E.; Dubery, I. A., Physiol. Mol. Plant Pathol. 2014, 88, 61-66.

16 Cole, R. A., Ann. Appl. Biol. 1984, 105, 129-145.

17 Leiss, K. A.; Maltese, F.; Choi, Y. H.; Verpoorte, R.; Klinkhamer, P. G. L., Plant Physiol. 2009, 150, 1567-1575.

18 Sauge, M.-H.; Poessel, J.-L.; Guillemaud, T.; Lapchin, L., Arthropod Plant Inter. 2011, 5, 369-377.

19 Sauge, M. H.; Lacroze, J. P.; Poessel, J. L.; Pascal, T.; Kervella, J., Entomol. Exp. Appl. 2002, 102, 29-37.

20 Rahbé, Y.; Delobel, B.; Febvay, G.; Massonie, G., Ann. Soc. Entomol. Fr. 1988, 24, 472.

21 Kodoma, M.; Wada, H.; Otani, H.; Kohmoto, K.; Kimura, Y., Phytochem. 1998, 47, 371-373.

22 Poessel, J. L.; Collet, M. H.; Rahbe, Y. N. E. Method for preparing dicaffeoylquinic acids and use thereof in combating aphids. FR2926955A1, 2009.

23 Antognoni, F.; Perellino, N. C.; Crippa, S.; Dal Toso, R.; Danieli, B.; Minghetti, A.; Poli, F.; Pressi, G., Fitoterapia 2011, 82, 950954.

24 Li, X.; Grand, L.; Pouleriguen, T.; Queneau, Y.; da Silva, P.; Rahbé, Y.; Poëssel, J.-L.; Moebs-Sanchez, S., Org. Biomol. Chem. 2016, 14, 2487-2497.

25 Corse, J.; Lundin, R. E.; Waiss, A. C., Jr., Phytochem. 1965, 4, 527-529.

26 Iwahashi, H.; Morishita, H.; Osaka, N.; Kido, R., Phytochem. 1985, 24, 630-632.

27 Morishita, H.; Iwahashi, H.; Kido, R., Phytochem. 1986, 25, 2679-2680.

28 Clifford, M. N.; Kellard, B.; Birch, G. G., Food Chem. 1989, 34, 81-88.

29 Kim, H. J.; Kim, E. J.; Seo, S. H.; Shin, C. G.; Jin, C.; Lee, Y. S., J. Nat. Prod. 2006, 69, 600-603.

30 Lee, S. Y.; Moon, E.; Kim, S. Y.; Lee, K. R., Bioorg. Med. Chem. 2013, 23, 2140-2144.

31 Clifford, M. N.; Johnston, K. L.; Knight, S.; Kuhnert, N., J. Agr. Food Chem. 2003, 51, 2900-2911.

32 Wang, Z.; Clifford, M. N., Food Chem. 2008, 106, 147-152.

33 Jaiswal, R.; Dickman, M. H.; Kuhnert, N., Org. Biomol. Chem. 2012, 10, 5266-5277.

34 Gutierrez Ortiz, A. L.; Berti, F.; Navarini, L.; Monteiro, A.; Resmini, M.; Forzato, C., Tetrahedron : Asymmetry 2017, $28,419-427$.

35 Jaiswal, R.; Kuhnert, N., J. Mass Spectrom. 2011, 46, 269-281.

36 Clifford, M. N.; Marks, S.; Knight, S.; Kuhnert, N., J. Agr. Food Chem. 2006, 54, 4095-4101. 
37 IUPAC CNOC and IUPAC-IUB CBN, Recommandations 1973 and Biochem. J., 1976, 153, 23.

38 Febvay, G.; Delobel, B.; Rahbe, Y., Can. J. Zool. 1988, 66, 2449-2453.

39 Rahbe, Y.; Febvay, G., Entomol. Exp. Appl. 1993, 67, 149-160. 